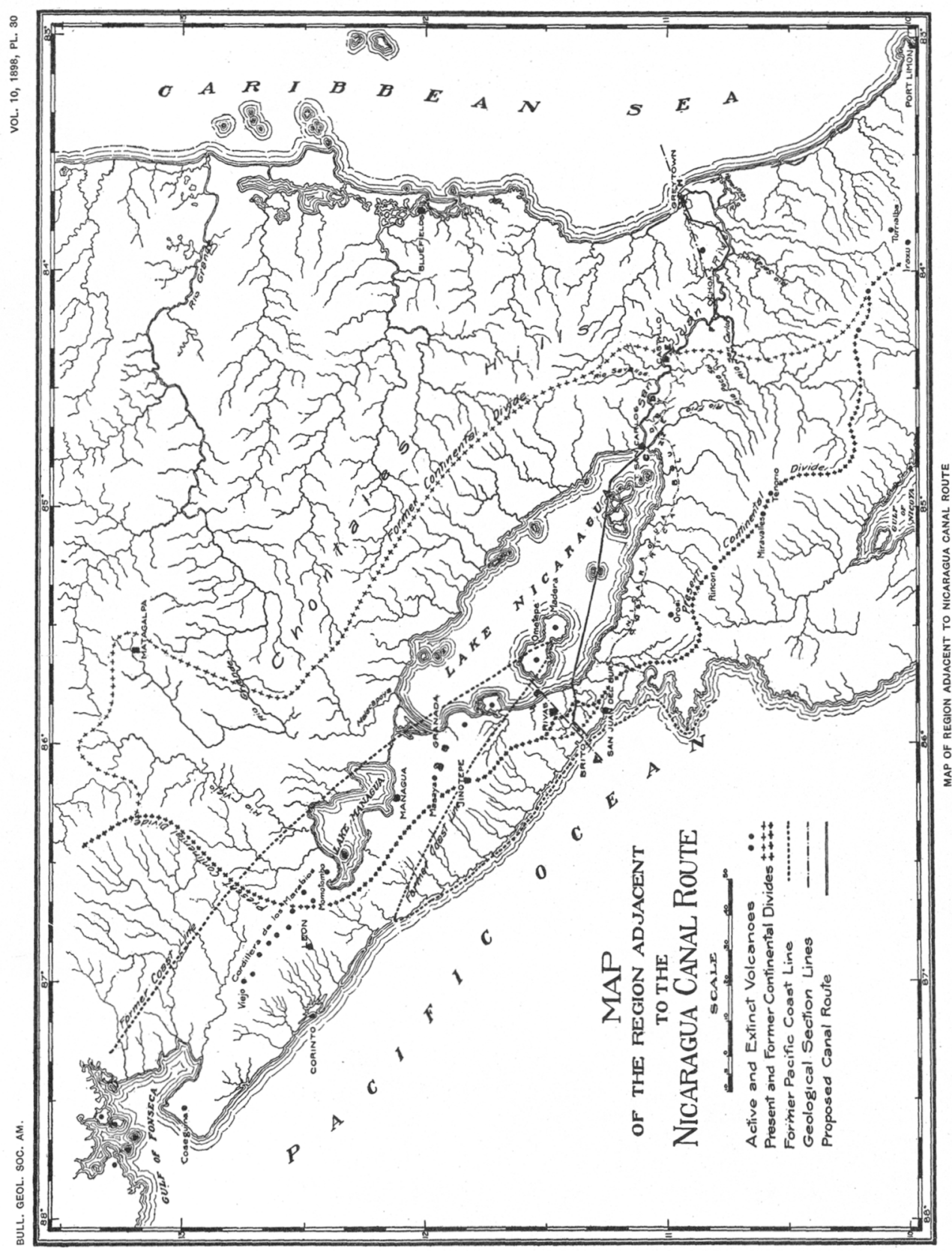




\title{
PHYSIOGRAPHY AND GEOLOGY OF REGION ADJACENT TO THE NICARAGUA CANAL ROUTE*
}

\author{
BY C. WILLARD HAYES
}

(Read before the Society December 29, 1898)

\section{CONTEN'TS}

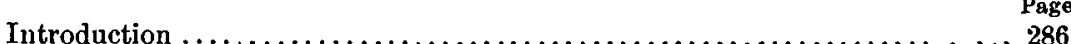

Topography $\ldots \ldots \ldots \ldots \ldots \ldots \ldots \ldots \ldots \ldots \ldots \ldots \ldots \ldots \ldots \ldots \ldots \ldots \ldots \ldots$

General character of the topography.................... 287

Classification of topographic features.................... 288

Types in general $\ldots \ldots \ldots \ldots \ldots \ldots \ldots \ldots \ldots \ldots \ldots \ldots \ldots \ldots \ldots \ldots$

Alluvial plains . . . . . . . . . . . . . . . . . . . . . . . . 289

Dissected peneplain.........................., 293

Residual hills. . . . . . . . . . . . . . . . . . . . . . . . . 298

Western divide . . . . . . . . . . . . . . . . . . . . . . . . 299

Lake-Caribbean divide. . . . . . . . . . . . . . . . . . . . 300

Volcanic mountain ranges. ........................... 301

Volcanic plateaus.................................... 304

Climate ........................................ 304

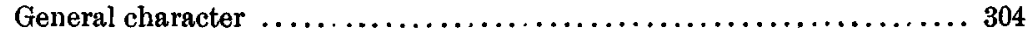

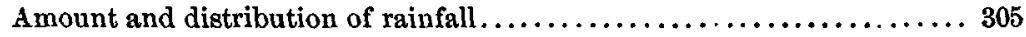

Physiographic effects. . . . . . . . . . . . . . . . . . . . . . 305

Eastern division $\ldots \ldots \ldots \ldots \ldots \ldots \ldots \ldots \ldots \ldots \ldots \ldots \ldots \ldots \ldots \ldots \ldots$

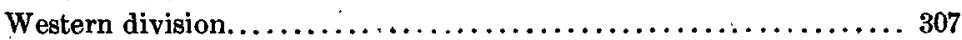

Rock formations. ................................. 308

Conditions for study $\ldots \ldots \ldots \ldots \ldots \ldots \ldots \ldots \ldots \ldots \ldots \ldots \ldots \ldots \ldots \ldots$

Classification of the rocks......................... 309

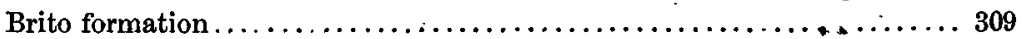

Distribution . . . . . . . . . . . . . . . . . . . . . 309

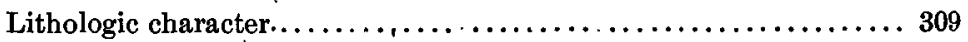

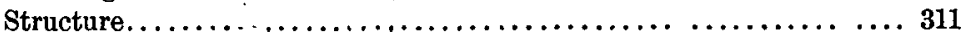

Age of the formation. $\ldots \ldots \ldots \ldots \ldots \ldots \ldots \ldots \ldots \ldots \ldots \ldots \ldots \ldots \ldots$

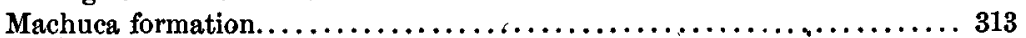

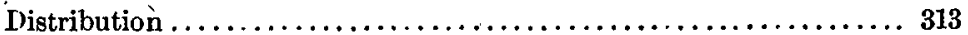

Lithologic character........................... 313

Structure. . . . . . . . . . . . . . . . . . . . . . . . . 313

Age of the formation $\ldots \ldots \ldots \ldots \ldots \ldots \ldots \ldots \ldots \ldots \ldots \ldots \ldots \ldots$

* Published by permission of Rear Admiral J. G. Walker, President of the Nicaragua Canal Commission. 


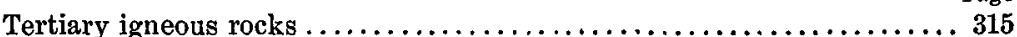

Location and general character $\ldots \ldots \ldots \ldots \ldots \ldots \ldots \ldots \ldots \ldots, \ldots \ldots \ldots$

Massive ígneous rocks................................. 316

Fragmental igneous rocks ............................ 317

Recent alluvial formations. . ............................ 319

Recent volcanic rocks............................... 320

Rock decay . ....................................... 322

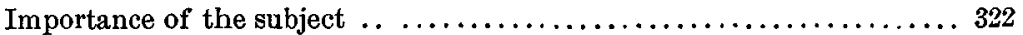

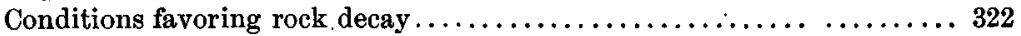

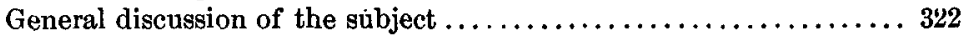

Effect of chemical composition......................... 323

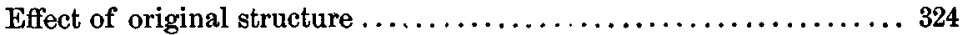

Effect of secondary structures ......................... 324

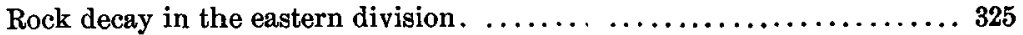

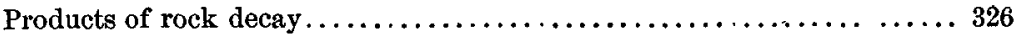

Classes in general. . . . . . . . . . . . . . . . . . . . . . . . . . . 326

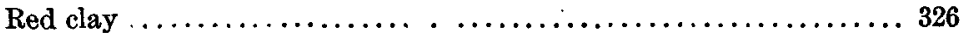

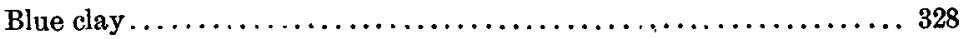

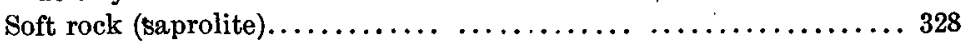

Rock decay in the western division $\ldots \ldots \ldots \ldots \ldots \ldots \ldots \ldots \ldots \ldots . \ldots . \ldots \ldots$

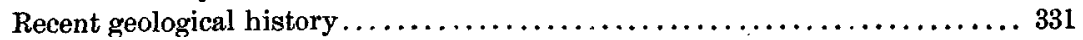

Relationship between topography and geology $\ldots \ldots \ldots \ldots \ldots \ldots \ldots \ldots . \ldots 331$

Conditions anterior to Tertiary time $\ldots \ldots \ldots \ldots \ldots \ldots \ldots \ldots \ldots \ldots \ldots \ldots \ldots \ldots$

Early Tertiary deposition and volcanic activity................. 331

Middle Tertiary uplift and erosion . . . . . . . . . . . . . . . . . 333

Post-Tertiary elevation and gorge cutting. $\ldots \ldots \ldots \ldots \ldots \ldots \ldots \ldots, \ldots \ldots \ldots$

Recent depression and alluviation $\ldots \ldots \ldots \ldots \ldots \ldots \ldots \ldots \ldots \ldots \ldots \ldots \ldots \ldots$

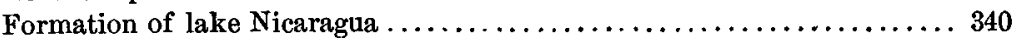

Subsequent modification of the lake $\ldots \ldots \ldots \ldots \ldots \ldots \ldots \ldots \ldots \ldots \ldots, \ldots \ldots$

Volcanic eruptions.................................. 344

Wave cutting..................................... 344

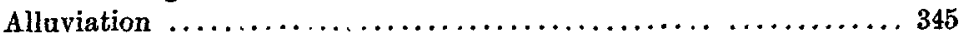

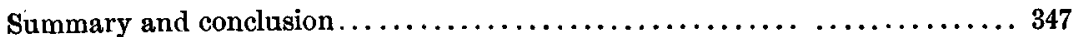

\section{INTRODUCTION}

The region discussed in the following paper embraces northern Costa Rica and southern Nicaragua. Its special interest lies in the fact that it contains the lowest gap in the Continental divide between the straits of Magellan and the Arctic ocean, and probably also contains the most feasible route for an interoceanic ship canal.

In connection with the investigations of the canal route by the United States Nicaragua Canal Commission, the writer spent ten months of 1898 in field-work in the canal region, the greater part of which was in the direction of drilling operations. In this way much detailed information 
was obtained concerning the geology immediately upon the canal route, but little opportunity was afforded for a general examination of the adjacent region. The conditions which prevail over much of the country, however, especially the presence of a luxuriant tropical vegetation and the depth of rock decay, entirely prevent, or at least greatly hamper, ordinary geological field-work. The only way in which reliable information concerning the underlying rocks can be obtained is therefore by means of the drill. The lack of more extended observations is most seriously felt in the paucity of information concerning the physiography of the region on either side of the San Juan river formerly occupied by the Continental divide. This region is densely forested, and, having no roads, is very difficult of access. It contains very few permanent habitations, and is visited chiefly by native rubber-hunters, so that its characteristics are very imperfectly known. Western Nicaragua, on the other hand, is not heavily forested, and contains a relatively dense population. For these and other reasons information concerning this portion of the region is comparatively full.

\section{TOPOGRAPHY}

\section{GENERAL CHARACTER OF THE TOPOGRAPHY}

The commonly accepted Humboldtian view of the topography of Central America should be definitely discarded at the outset. According to this view, which is still dominant in the text-books, a continuous mountain chain connects the Cordilleran system of western North America with the Andean system of western South America. Hill * has fully demonstrated the falsity of this old view and shown the complete independence of the orographic systems of the three Americas. The due east-and-west trend of the Central American mountain chains is perhaps less prevalent than Hill has represented it. In the region under discussion, at least, there is a distinct northwest-southeast trend in all the larger topographic features. The same trend predominates in the geologic structures, and the two are doubtless in some measure connected. The north west-southeast trend is observed in the ranges of volcanic peaks which cross the isthmus diagonally from the Caribbean sea to the Pacific in northern Costa Rica and western Nicaragua. It is also, though less distinctly, seen in the Chontales hills between the Caribbean sea and the lakes, and again in the great depression which extends diagonally across the isthmus be-

* Robert T. Hill : Fundamental Geographic Relations of three Americas. Nat. Geog. Mag., vol: vii, 1896, pp. 175-181. 
tween the volcanic ranges on the southwest and the Chontales hills on the northeast.

\section{CLASSIFICATION OF TOPOGRAPHIC FEATURES}

Types in general.--Three distinct types of topography are encountered in this portion of Central America, namely :

Oldland areas with maturely developed degradational surfaces.

Recent volcanic cones and plateaus with slightly modified constructional surfaces.

Recent floodplains and deltas with still forming aggradational surfaces.

The oldland occupies much the larger portion of the region represented on the accompanying map. It forms most of the San Juan valley, and expands northward between the divergent lines of the Caribbean coast and the Nicaragua-Managua lake basins. It also forms the narrower portion of the land strip between the former lake and the Pacific. This part of the region appears to have been above sealevel since the middle of the Tertiary, and the form of its surface is due entirely to the action of subaerial gradational forces. Although composed largely of volcanic materials, the original constructional surfaces appear to be entirely obliterated.

The recent volcanic cones constitute two ranges-the Costa Rican range, terminating in the volcano Orosi, and the parallel Nicaraguan range, which extends from Madera northwest to the gulf of Fonseca. The eruptions which gave rise to the Costa Rican range appear to have broken out on a somewhat elevated land surface, perhaps similar in age and topographic development to the present Chontales hills. The northern series of eruptions, on the other hand, occurred on the sea bottom along a line near the center of a bay which formerly indented the Pacific coast. Most of the volcanoes constituting these two ranges are extinct, or at least quiescent, but they are so recent that their constructional slopes are only slightly modified by subsequent erosion. The same is true of the gently sloping volcanic plateaus from which rise the cones of the northern range.

The floodplains and deltas form a comparatively small part of the region, but their importance is out of proportion to their extent, particularly from the viewpoint of the canal engineer. By a recent depression of the land all the streams entering the sea have been drowned and the estuaries thus formed have been silted up. The deltaplains are the seaward extension of the floodplains, and hence are the most recent topographic forms of the region, and the method of their formation may still be observed in active progress. 
The various topographic features mentioned in the above primary classification may now be taken up and described somewhat more fully. Since the oldland occupies the largest area and has more complex forms of relief, which are intimately connected with the recent history of the region, greater attention will be devoted to this division, and particularly to that portion of it which constitutes the Nicaraguan depression.

When examined in detail the surface of the oldland is found to have considerable diversity in its relief, and its topographic forms naturally fall into three classes. These are (1) fairly well developed peneplains, which rise gradually from either coast toward the axis of the isthmus until recent geologic time occupied by the Continental divide; (2) many valleys which intersect the surface of the peneplain, having been cut during a period of high level and subsequently depressed below sealevel, and (3) residual hills which rise distinctly above the peneplain surface and are most numerous toward the axis of the isthmus along the former Continental divide.

For convenience of description the valleys will be taken up first, and since these have been silted up by recent alluvial deposits, the floodplains and the coastal deltaplains will be described at the same time.

Alluvial plains. - The coastal plain on the Atlantic side of the isthmus increases from a mere fringe at the base of the mountains in Costa Rica northward to a belt from 10 to 15 miles wide in the vicinity of Greytown. It is formed wholly of materials brought down by the rivers heading in the Costa Rican volcanoes - is in fact a series of coalescing deltas, of which the largest is that formed by San Juan river. The sediment brought down to the sea by streams north of the San Juan is very small compared with that brought down by those to the south. The more rapidly growing southern deltas would therefore be extended seaward except for a strong northward littoral sand current set up by the oblique direction at which the prevailing winds strike the shore. The true littoral current in this portion of the Caribbean sea is to the southward, but its capacity for transporting sediment is more than neutralized by the active northward sand drift within the zone of surf action. This sand drift tends to distribute the sediment evenly along the coast and preserve gently curving coastlines. Notwithstanding this tendency, the San Juan delta has been built out a short distance into the Caribbean, forming a shallow embayment to the northward of Harbor Head.

The level surface of the deltaplain is interrupted by numerous low rounded hills composed of residual clay derived from the decay of rock in situ, and differing decidedly in appearance and composition from the surrounding alluvium. These hills have the form and appearance of islands rising above the level deltaplain, and it is quite probable that they 
were at one time islands fringing the shore before the alluvial deposits extended out to them and connected them with the mainland.

The inner margin of the deltaplain is extremely irregular. The isolated hills increase in number and size and finally merge with the dissected interior highland, while the deltaplain itself merges with the broad floodplains of the streams.

The surface of the deltaplain in its seaward portion is but a few feet above tidelevel. Its extreme outer margin is marked by low ridges parallel with the shore, formed by the sand thrown up during exceptional storms. From the shore margin the surface of the plain ascends toward the interior at a fairly uniform rate of about 28 inches to the mile.

The surface of the deltaplain is also diversified by numerous small lakes and lagoons. 'These are produced chiefly by the formation of sandspits and by unequal sedimentation.

Sediment is delivered by the larger streams slightly faster than it can be distributed by the littoral current; hence it tends to build out a delta; but this is deflected in the direction of the current and forms a curved sandspit, which for a time makes a well sheltered harbor. As the sandspit continues to grow, however, its point eventually joins the mainland, and the harbor is converted into a closed lagoon. This complete cycle of changes has taken place at Greytown during the last century and a half. The cycle has also been repeated at the same point several times previous to the last, giving rise to the several distinct lagoons which occur back of the one last formed.

The second method by which lagoons are formed on the deltaplain is by unequal seaimentation. As the coast was built outward by additions to its outer margin it advanced past numerous islands fringing the shore and which in some cases prevented the uniform deposition of sediment by interrupting the littoral sand stream, and these areas, in which little or no deposition took place, subsequently formed lakes. Perhaps the best example of a lake formed in this manner is lake Silico. This occupies what was evidently at one time a bay sheltered by the Silico hills, which then formed a group of islands. As the deltaplain was built out, connecting these islands with the mainland, the sheltered bay was not filled by sediment, but its opening was cut off and a lake thus formed.

Another class of lakes or lagoons formed by unequal sedimentation is found about the margins of the deltaplain and the river floodplains. The rivers which head upon the Costa Rican volcanoes carry a much more abundant supply of sediment than the smaller streams which flow from a region composed of compact residual clays protected by a heavy mantle of vegetation. Hence the floodplains of the larger streams, as the San Juan, are built up more rapidly than those of their tributaries. 


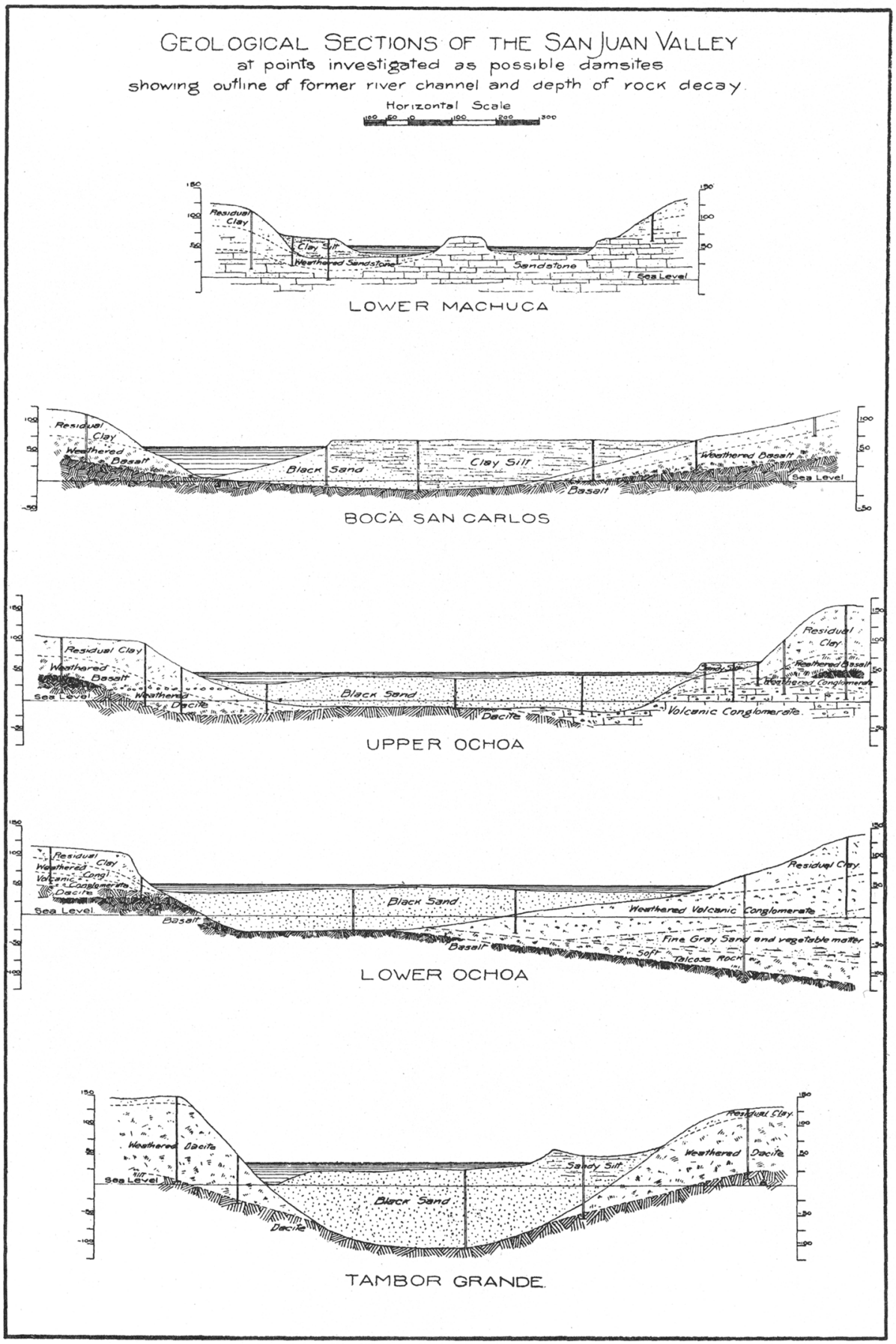

GEOLOGICAL SECTIONS OF SAN JUAN VALLEY, NICARAGUA 
The latter are therefore dammed and form lagoons in their upper basins. The Florida lagoon is a typical example of this class.

The lagoons of the deltaplain formed in these various ways are at first open lakes, but they gradually become choked by vegetation and filled with fine silt, so that they are converted into grassy marshes, and finally, when the silt becomes sufficiently consolidated to form a stable support, the forest trees encroach on the marsh and all trace of the lagoon is lost. Numerous examples occur on the deltaplains illustrating every step in the process: first the open lagoon, then the floating grass mat, then the silico swamp, and finally the heavy forest.

As already indicated, the deltaplain at its inner margin merges with the broad floodplain of the San Juan river, and any line separating the two would be purely arbitrary. For convenience, however, the head of the delta may be placed at the point where the first distributary, the San Juanillo, leaves the main stream.

Most.floodplains are formed by the lateral cutting of streams as they swing from side to side in their valleys. A plain thus cut in the underlying rocks is usually covered with a thin sheet of alluvial material. The floodplains of this region, however, belong to a totally different class. They include no level plains cut in the underlying rock or residual material which covers the rock. On the other hand, the alluvium has very considerable depth, and, instead of forming a layer of uniform thickness, fills a series of old stream channels. It is evident that these channels were formed when the land stood higher than now, for many of them extend below sealevel. There is thus an old land surface concealed beneath the alluvial deposits, and a consideration of its topography becomes a matter of prime importance to the engineer. This buried topography will be considered more fully in connection with the unburied portion of the same surface-that is, the surface of the hills rising above the margins of the alluvial plains (see plate 31 ).

Extensive floodplains extend up the San Juan river to the mouth of the San Carlos. Above this to the head of the Toro rapids the river flows in a comparatively narrow gorge, and its floodplains are narrow and inconspicuous. From the Boca San Carlos downward to the head of the delta, floodplains are always present on one or both sides of the river, though they are most extensively developed on the south side. The surface is slightly higher near the river, forming the natural levee which characterizes most floodplains. The outer margins are depressed and occupied by swamps or lagoons. The surface of the floodplains in. the vicinity of the Boca San Carlos varies from 15 to 20 feet above the river at ordinary low stages. As the plains become more extensive downstream their surface is slightly less elevated, since the floods which 
deposit the alluvium, having opportunity to spread over a much larger area, do not rise so high.

The slope of the floodplains from the Boca San Carlos to the head of the delta is about 11 inches per mile. This slope is dependent on the volume of the river and the character and quantity of the sediment which it carries. It is therefore much steeper below the mouth of the San Carlos than above, for it is from this stream that the greater part of the coarse sediment in the lower river is derived.

As stated above, the floodplains are inconspicuous from the Boca San Carlos to the head of the Toro rapids. The river flows in a comparatively narrow gorge and is generally bordered by rather steep hills, which approach nearly to the river channel. At the head of the Toro rapids, however, the valley widens, and from this point to the lake the river is everywhere bordered on one or both sides by extensive floodplains. Although their general relations to the river are similar to those bordering its lower course, they yet differ in some important particulars. They have been formed by sediment borne, not by the river itself, but by tributaries coming into the valley on either side. They thus have the form of coalescing deltas. The natural levee, which is a conspicuous feature in the floodplains of the lower river, is absent, and the plains generally show a gradual descent from their outer margins toward the river. Hence there are no lagoons on the tributaries such as are found on the tributaries of the lower river, and the floodplain becomes gradually firmer and more heavily wooded with increasing distance from the river. From the mode of formation of these plains it is manifest that the river is in a stable position and does not show that tendency to seek a new channel which is characteristic of delta streams.

Most of the streams entering lake Nicaragua on its northeastern side at one time entered the heads of estuaries. These estuaries have been almost entirely filled with alluvial deposits, and in some cases somewhat extensive deltas have been built out into the lake. The absence of a surf in this portion of the lake, except on rare occasions, owing to the direction of prevailing winds, permits the building of deltas which carry the distributaries of the streams a considerable distance out from the general shore line. The most extensive alluvial deposits about the lake are at its southern end. This portion of the lake basin appears to have been originally rather shallow, and the sediment brought in by streams from the south, notably by the Rio Frio, has considerably contracted its area. The newly added land forms about the margin of the lake an extensive swamp, through which the streams meander in a network of interlacing distributaries, all more or less obstructed by vegetation. The land becomes gradually firmer at increasing distances from the lake, and finally 
passes into an ordinary alluvial floodplain. Streams entering the lake from the southwest in general flow in channels which were at one time excavated to a very inconsiderable depth below the present surface of the plain through which they flowed. This plain, it may be remarked in passing, is not alluvial, but is a plain of degradation; hence these streams are bordered by very inconsiderable alluvial plains, and that only near the lake. The streams entering the Pacific from this portion of the isthmus are all short and consequently small, since the Continental divide is near the west coast. They occupy valleys which have been cut to a much greater depth than they have at present, and these old valleys have been recently drowned and more or less perfectly filled with alluvial deposits. Where the filling is not quite complete an estuary occupies the old river valley and forms a harbor, as is the case at San Juan del Sur. Where the filling is complete, as in the valley of the Rio Grande, the beadlands which mark the margins of the former deep valley are connected by a curved beach, which does not indent the coast to any appreciable extent. The depth of the alluvium in the Rio Grande valley varies from about 40 feet at the head of the floodplain to something over 100 feet at the coast. The stream which has filled this valley carries at certain seasons an abundant supply of sediment, so that the seaward slope of the floodplain is rather steep, a little over 10 feet to the mile. The conditions in this region which determine the rate of erosion are much more favorable to rapid degradation of the surface. than in the region of much greater rainfall to the east, where the rain is distributed evenly throughout the year. The streams are alternately shrunken to mere rivulets and swelled to torrents, and the resulting floodplain has somewhat the character of an alluvial cone.

Dissected peneplain.-The group of topographic forms to be described next in order after the alluvial plains consists of a more or less completely dissected plain or peneplain of degradation. In order to understand the present topography it is necessary to consider the original form of this plain and the manner in which it was developed. The conditions which prevailed prior to its formation cannot be definitely determined, but may be inferred in a general way. There was probably a somewhat elevated plateau, growing broader and higher both to the northward and the southward from a somewhat constricted region, now occupied by the Nicaraguan depression. The Continental divide at that time probably occupied a position near the central part of the isthmus, crossing the present San Juan valley in the vicinity of the Castillo rapids, and streams heading upon this divide flowed to the seas on either side. Another important difference was in the form and position of the Pacific coastline. These differences in the geography of the region, so far as 
they can be inferred, are represented on the accompanying sketch map (plate 30). It will be noted that lake Nicaragua did not then exist. Its present basin was occupied in part by a bay indenting the coastline and in part by the basins of rivers tributary to this bay. The region occupied by the volcanic peaks of the Nicaraguan range and the volcanic plateau west of the lake was then occupied by the sea. A cape projecting northward between the sea and the bay was composed of low hills, now forming the Continental divide southwest of the lake.

In still other respects the drainage of the region during the formation of this peneplain differed from the present. The San Juan river receives only small tributaries from the north, while it receives both small and large from the south. The large tributaries include the Frio, Poco Sol, San Carlos, and Sarapiqui. These all head on the slopes of the Costa Rican volcanic range, which forms the southern margin of the Nicaraguan depression. The upper portions of these streams are normal to the mountain range, the axes of their valleys being at right angles to the axis of the range, and also to the general course of the San Juan. Midway of their courses, however, there is an abrupt change in direction. T'he Frio and Poco Sol bend westward, while the San Carlos and Sarapiqui bend eastward, the axes of the lower valleys in every case making a rather acute angle with the course of the San Juan. It seems probable that when the peneplain was being developed in this region the two rivers whose basins now form that of the San Juan occupied the axes of those basins, receiving tributaries of equal length from either side. The volcanic eruptions to the south, however, obliterated the former drainage of that region, and the consequent streams developed on the flanks of the newly formed mountains were turned northeast, discharging into the heads of the preexisting small tributaries. It thus appears that the four above named southern tributaries of the San Juan have composite courses. Their upper courses, normal to the trunk stream, are consequent on the constructional slope of the recent volcanic range; their lower courses, making acute angles with the trunk stream, are inherited from the normally developed, small tributaries of two streams flowing respectively southeast and northwest.

The rapidity with which the streams heading upon the Continental divide reduced their valleys to baselevel depended chiefly upon the character of the rocks which they encountered, while the rate at which the divide was lowered by the action of opposing streams depended on the character of the rocks and the distance of the divide from the coast or the width of the isthmus. The region to the northward is probably occupied by the older and more resistant rocks, including gneisses, schists, and quartzites. Of that to the south very little is known, since 
its topography has been entirely changed and its older rock formations concealed by the recent eruptions of its volcanoes. From this combination of circumstances it followed that the surface was most completely degraded and the divide most rapidly lowered along a belt extending diagonally across the isthmus and now forming the great Nicaraguan depression. A broad river basin was developed on the east side of the divide, occupying the present position of the lower San Juan basin. The land between its various southern tributaries was reduced to low relief. Its northern tributaries were separated by somewhat higher hills, probably the result chiefly of the greater original elevation of this portion of the region. Another river system developed a similar basin with its outlet to the west. The several upper tributaries of each of these two river systems headed on the Continental divide in low gaps against the tributaries of the other system. The basin of the western system was somewhat larger than the one on the east of the divide. Its lower portion was separated from the Pacific by a range of hills which continued northwestward, forming the cape between the then existing bay and the ocean. The southern portion of the present basin of lake Nicaragua was occupied by this river system, and extensive plains were developed on either side of the axis extending up the tributaries as broad valleys well back into the surrounding hills.

The foregoing brief account of the original extent of this peneplain and the rnanner in which it was formed is an essential preliminary to an understanding of the present topogra phy. At the conclusion of the long period of degradation, during which the surface of the region now occupied by the Nicaraguan depression was reduced to a low relief, the land was slowly elevated until it stood some hundred feet higher than before and perhaps 200 feet higher than now. The elevation stimulated the streams to renewed activity, and they began trenching the valleys which they had previously formed. The erosion was at first most active near the coast, and worked backward toward the interior most rapidly along the largest streams. The portions of the peneplain most completely dissected were therefore its outer margins. Here the surface was almost entirely reduced to the lower baselevel, and only a few rounded hills on the divides retained any trace of the former plain. The first of these remnants seen on ascending the San Juan are in the vicinity of the delta head where low hills approach the river on the north side. This region, however, has been so deeply dissected that the hilltops scarcely suggest the existence of a former plain. Other hills of similar character occur along the river, chiefly on the north side, although the most prominent hills which come down to the river do not belong to the group now being described, but to the residual hills which rose above 
the surface of the old plain at the time of its most perfect development. The remnants of the dissected plain increase in number and in the regularity of their summits until, in the vicinity of Ochoa, their uniformity is such that the position of the old peneplain can be accurately determined. The dense tropical forests mask the minor topographic features, so that the uniformity in the summits of the hills is not at once apparent. The detailed contour maps, however, of those portions of the region which have been actually surveyed exhibit the uniformity in a striking manner. The present elevation of the hilltops in this region is about.150. feet above sealevel. To the south of the river the old plain was very extensively developed, and while it has suffered much subsequent dissection, there is a large area in which its former position can be readily determined by the summits of the present hills. To the north of the river it was less extensive, forming only broad valleys between the residual hills which occupied the divides. Although not so extensively developed here as south of the river, the plain has been somewhat better preserved, and many streams are found which have not yet lowered their valleys appreciably below the old surface. Heading on the steep residual hills, their upper courses are in sharply cut V-shaped valleys. Emerging from these, they flow in shallow valleys across the remnant of the old plain, their channels meandering and obstructed by swamps. Farther down they enter narrow gorges which they have cut and are still deepening in the old peneplain. Still farther down they are bordered by alluvial plains, where the valley's which they cut in the old plain have been depressed below baselevel and so silted up.

Continuing westward from Ochoa, the summits of the hills become less uniform in altitude, corresponding with the originally less perfect development of the old peneplain in the vicinity of the former Continental divide. Along the upper portion of the river, west of the Toro rapids, are numerous low, rounded hills merging on either side of the valley with a more continuous upland, and these probably mark the position of the former peneplain. It slopes gently westward and probably passes beneath the waters of lake Nicaragua. The broad valleys bordering the streams which enter the northeastern side of the lake and the level plain which forms the western margin of the lake basin probably constitute parts of this old plain, which have here almost entirely escaped dissection.

In connection with the remnants of this old peneplain, the topography of the surface now concealed by the alluvial deposits should be considered. At the close of the period of high level, during which the plain was dissected, the valleys were rather narrow with steep slopes except near the coast. If the subsidence which inaugurated the period of alluviation had occurred all at once, tidewater would have extended up the 
valley of the San Juan river beyond the Boca San Carlos, and also some distance up its tributaries. It is probable, however, that the land sank very slowly, so that the estuaries were never deep, but were filled by alluvium almost as fast as formed. The depth of these old valleys having been determined by borings at various points on the trunk stream and some of its tributaries, it is possible to reconstruct the former surface and determine approximately the depth of the alluvial filling in any part of the drainage system. It is found that the erosion of the hills has been inconsiderable, since the submergence for the slopes above the margin of the floodplains are practically the same as the old slope beneath the alluvial cover. The valleys of the lower San Juan and its tributaries have been filled in such a manner that the present streams follow very nearly the same course as the streams which formed the valleys. In some cases their meanders have carried them to one side or the other of the old valley, where they are now cutting against the bordering hills of residual clay. The form of the old San Juan valley is shown on plate 31 .

The original form of the surface concealed by the floodplain of the upper San Juan is much more difficult to make out. 'This plain was formed by deposition in quiet water, the river valley being entirely drowned. Hence the present channel was not determined by the deepest portion of the old valley, but by the relative amounts of sediment brought into this portion of the lake by tributaries on either side. It is evident that the stream bearing the largest amount of sediment is the Rio Frio, and the delta of this stream has pushed the outlet of the lake northward away from the deeper portion of the old valley and against the hills which formed its margin. The same thing is seen at various points between the lake and the Toro rapids. At numerous points the meanders of the river carry it away from the deeper portions of the old valley and against the marginal hills. In most cases these meanders are not accidental, but are determined by the entrance of a tributary on the opposite side. It is therefore impossible to determine the position of the stream which formerly occupied this valley from the present position of the San Juan. Sufficient boring has been done in this portion of the river channel, however, to determine the fact that the rock or residual clay slopes of the hills which at present rise above the alluvial plain continue practically unchanged beneath the alluvium. The importance of this fact in the location of the canal line is at once apparent. The line in general follows the channel of the river, but if this were strictly followed considerable rock excavation would be necessary where the channel swings against one of the marginal hills. It is evident, however, that by shifting the line away from the hill the rocky slope will pass below the 
bottom of the canal, so that the excavation necessary to secure the required depth will be entirely in alluvium.

Residual hills.-The third group of topographic forms which characterize the old land area embraces the hills rising distinctly above the present tops of the lower hills and representing portions of the surface never reduced to the level of the old peneplain. The summits of these hills are entirely different from the dissected remnants of the peneplain above described. The crests are always sharp and serrate, with no uniformity whatever in their altitudes.

The hills of the Eastern divide lying between the basins of the Deseado and San Francisco form a characteristic group belonging to this class.

Their slopes are extremely steep and their sides are furrowed by sharp $\mathrm{V}$-shaped ravines. Around their base are remnants of the old plain above which they formerly rose, now appearing as rounded hills with uniform summits. Long spurs radiate from the central mass of the Eastern Divide hills and reach the San Juan river at several points, forming the high ridges at Sarapiqui, Tamborcito, Tamborgrande, and San Francisco. Another prominent group of hills belonging to this series occurs at the junction of the San Juan and San Carlos. These have a form similar to that of the Eastern Divide hills, but the group is somewhat smaller. The upper slopes are extremely steep and the sides are deeply gullied, while the summit as seen from either side presents a sharply serrate outline. The altitude of the San Carlos hills is about 1,200 feet. These isolated groups of high hills occur with increasing frequency toward the line formerly occupied by the Continental divide, which probably crossed the present valley of the San Juan in the vicinity of Castillo. West of this line they decrease in frequency and hight to the lake.

The residual hills which rise above the peneplain of the Nicaraguan depression increase in hight and numbers toward the north, finally merging with the mountains of northern Nicaragua, where they reach elevations from 6,000 to 7,000 feet above tide. Comparatively little is known of any portion of this region except its western margin. The eastern part is covered with a dense tropical forest, is almost entirely without settlement, and has been only partially explored. The divide between the lake and Caribbean drainage passes some distance to the westward of the axis of the isthmus, being approximately parallel with the Pacific coast northwestward to the Matagalpa river, where it makes an abrupt bend to the eastward, passing around the basin of that stream. This region between the lake and the Caribbean may be described as a deeply dissected upland. During Tertiary time it was doubtless the locus of intense volcanic activity, but subsequent erosion has entirely 
destroyed all trace of the original constructional topography, and the location of the vents by which the volcanic rocks were erupted can not be determined from the present form of the surface, though it might be determined by a systematic study of the distribution and variations in character of the volcanic rocks. Toward the northern end of the lake, opposite Granada, the summits of the hills present an even skyline, as though they were remnants of a plateau; but this surface may be a degradational rather than a constructional plain. The streams flowing into the lake have baseleveled their valleys for a considerable distance back in to the upland, but are separated by sharp ridges and hills which occupy the divides. Although the higher portions of the divides attain somewhat uniform altitudes which increase northward, the uniformity is not sufficient to determine the former existence of a distinct plain, and it is probable that the present valleys are carved in a surface which, since its final emergence above sealevel, has always had rather high relief.

Western divide.-As already indicated, the great Nicaraguan depression was formed before lake Nicaragua came into existence. It originally extended entirely across the isthmus, terminating to the westward at the bay which then indented the Pacific coast, a cape projecting to the northwest between this bay and the ocean. 'The cape now forms the narrow strip of land lying to the southwestward of lake Nicaragua and separating it from the Pacific. This strip of land is not properly, therefore, a part of the Nicaraguan depression, and its topography should be independently considered.

Bordering the southwestern shore of the lake and extending northwestward nearly to Zapetara island is a very perfectly baseleveled surface, termed for convenience the Rivas plain. It varies in width from 5 to 12 miles, and is continuous along the lake margin, except near the Sapoa river, where it is interrupted for a short distance by high hills coming down to the lake. Very little is known concerning the southeastern extension of this plain, but it is probably nearly or quite continuous around the end of the lake with the peneplain of the Nicaraguan depression already described. Its northeastern margin is the lakeshore, where the waves have cut a shallow terrace backed by a cliff from 10 to 40 feet in hight. A few low, rounded hills rise above its even surface, but they seldom attain hights of more than 100 feet. In the vicinity of Rivas, where it is most thoroughly known, the plain ascends toward the southwest, at the rate of about 8 feet to the mile, to the base of the hills which occupy the greater part of this strip and form the Continental divide. These hills rise abruptly from the Rivas plain to hights of 800 to 1,200 feet above tide, and extend northward to a point opposite the island of Zapatera, where they meet the Jinotepe plateau, and the ser- 
rate residual outline of the former gives place to the even constructional slope of the latter. A single break occurs in this continuous line of hills. This is the gap between the waters of the Rio Lajas and of the Rio Grande. Here the level plain bordering the lake extends entirely through the range of hills, forming a low, broad gap whose summit is but 50 feet above the lake.

The manner in which this single low gap was formed is described at some length in a later part of this paper, where the recent geological history of the region is given. It may be stated here, however, that the gap is the product of the familiar process of stream capture. Owing to the decided advantages possessed by the streams flowing directly to the Pacific over those flowing eastward, at first to the bay of Nicaragua and afterward to the lake, the former were able to cut back through the divide into the drainage area of the latter and to divert their headwaters. In this way an eastward-flowing stream originally occupying the position of the Tola, the upper Rio Grande, the Guiscoyol, and the Lajas was beheaded, and the drainage of a large part of its basin was diverted to the Pacific. The deserted valley of this stream forms the low gap through which the canal route is located. It is so broad and level that accurate instrumental work is required to determine the actual summit of the Continental divide.

The Pacific coast in the southern part of this region is formed by alternating short strips of sandy beach and bold, rocky promontories. The stretches of beach are formed by the silting up of deeply cut valleys, and the promontories by the truncated points of ridges which extend down to the coast between the valleys. To the northward of Brito the proposed western terminus of the canal, at the mouth of the Rio Grande, the hills are farther inland and fewer spurs reach the coast. A coastal plain of some extent is here developed, increasing in width to the north until it passes beneath the recent volcanic deposits which form the Jinotepe plateau.

This coastal plain probably at one time passed around the northern end of the divide hills and was continuous with the Rivas plain to the east. With the formation of the Jinotepe plateau the tuffs of which it is composed buried this northern portion of the plain and piled up against the end of the divide hills three or four hundred feet in thickness.

Lake-Caribbean divide.-The much greater rainfall in the enstern portion of the isthmus has given the Caribbean streams a decided advantage, and they have pushed the divide westward probably some distance from its original position. A few cases occur'which clearly indicate stream diversion. The most striking of these is the upper portion of the Rio Grande, which flows to the Caribbean north of Bluefields. This 
river heads in the high valley of Matagalpa, from which it flows south westward for 35 miles, approaching the Viejo within about 5 miles, being separated from that stream by a level swampy plain. The Viejo flows southwest to the upper end of lake Managua, and it is entirely probable that the upper portion of the Rio Grande was formerly a tributary. of the Viejo. From the point where it approaches most nearly to the Viejo it flows southward for a distance of 25 miles, and this southerly direction is continued in a tributary which enters at that point. This portion of the stream appears to have been at one time a part of the Malacapoya, which enters the head of lake Nicaragua. From the point of nearest approach to the Malacapoya the Rio Grande turns abruptly back to the northeast, and for a distance of 30 miles is approximately parallel to its upper course in the valley of Matagalpa. It appears highly probable that the Rio Grande, by reason of the greater rainfall in the eastern part of this region, pushed the divide westward until its headwaters intercepted the upper portion of the Malacapoya. The same process was continued and the extended headwaters effected another conquest, diverting a large tributary of the Viejo. The latter capture has been so recent that the channel of the diverted stream has not been perceptibly lowered, and a part of its waters in the wet season may still follow their former course to the Viejo across the intervening swampy plain. A few other cases of stream diversion are indicated by the character of the present stream channels, but none of them are so striking or important as that of the Rio Grande.

Volcanic mountain ranges.-As indicated above, the southern margin of the Nicaraguan depression is formed by the foothills of the Costa Rican volcanic range. This range terminates to the northwestward in the probably extinct volcano Orosi. It contains a large number of volcanic peaks, most of which are extinct and a few quiescent or moderately active. These peaks have a striking linear arrangement and form two nearly parallel lines of vents. The line terminating in Orosi extends southeastward into Costa Rica, passing to the southward of a parallel range whose northern peak is the volcano Turrialba: These two lines are about 10 miles apart, but their peaks are so high that their slopes merge and they form a single range. If the line connecting the northeastern series of peaks were continued to the northwestward through the southern portion of lake Nicaragua it would coincide very nearly with the line connecting the peaks of the Nicaraguan range. The latter range terminates to the southward in the extinct volcano of Madera; thence it stretches to the northwest, terminating in the volcano Coseguina, which occupies a peninsula projecting into the gulf of Fonseca. Between these two extreme peaks there is a large number of extinct, quiescent or active vol- 
canic vents forming more or less isolated mountains. Of these Ometepe, Masaya, Momotombo, and several others to the northwest of the latter have been in eruption within historic times. Others are in the solfataric stage, while still others appear to be entirely extinct. The group of peaks between Momotombo and Coseguina is called the Maribios range.

It is probable that the vents which formed the Costa Rican range broke out upon a somewhat elevated plateau, while those which formed the Nicaraguan range broke out on the sea bottom. The latter, also, are farther apart, except those northwestward of Momotombo, which form the Maribios range. This may explain the greater hight and massiveness of the Costa Rican range, and the amount of material erupted from the two series of vents may not differ greatly.

As already indicated, it is probable that the form of the coast has been materially modified by this recent volcanic activity. The whole of the country between the northern portion of lakes Nicaragua and Managua and the Pacific consists entirely of recently ejected volcanic material, and the region which it now occupies was doubtless a portion of the Pacific until recent geologic times. The former coastline is represented on the sketch map forming plate 30 .

The surface of this newly added land is composed of level or gently sloping plains, isolated conical volcanic peaks, and the more crowded peaks of the Maribios range. Types of the entirely isolated peaks are Ometepe and Momotombo. Both of these are composed of alternate layers of lava and ash. The latter, however, gives them their perfect conical form. Both have been in eruption within historic times, and considerable smoke still comes from Momotombo. Only a small amount of steam and sulphurous vapors are at present emitted from the crater of Ometepe.

Modification by the ordinary processes of erosion, in the form of these steep cones of unconsolidated ash, is extremely rapid, and their summits vary in detail of outline from year to year. Madera and Zapatera are volcanoes, which have been extinct for some time, and the agents of degradation have materially reduced their hight and destroyed the original conical form of their summits. The unconsolidated ash has been largely removed from their upper portions, leaving only the massivelava beds in place; hence their formation has been ascribed to a different form of eruption from that which produced Ometepe and Momotombo. It is probable, however, that the summits of the former once consisted of ash cones, and that the eruptions in all have been accompanied by more or less explosive violence, to which the unconsolidated fragmental material is due. The lower slopes of Mombacho are rather smooth and symmetrical; but instead of a single cone its summit is truncated and 
forms a series of ragged peaks, which surround a deep depression occupied by a small lake. There is a tradition that this mountain formerly had a conical summit, which was destroyed by an explosive eruption. The present appearance of the mountain makes it extremely probable that this tradition is based upon fact. Its outline closely resembles that of Coseguina, and, as is well known, the latter was formerly capped by a symmetrical cone, which was blown off in the explosive eruption of 1835. This was perhaps the most violent recorded eruption of this character up to the time of the eruption of Krakotoa in 1883. Since this final burst of activity Coseguina has remained perfectly quiet. The volcano of Masaya, which erupted a flow of lava in 1858, is at present a mountain of moderate hight, about 2,200 feet. It occupies the position, however, of a mountain which may once have been very much higher. The former volcanic peak occupying this position was destroyed, not by an explosive eruption, but by engulfment. The peak now occupies a depressed area, having an oval shape and regular outline, about 4 by 6 miles. It is located a little north of the center of this depression, the northern portion of which its lavas have nearly filled, flowing out over the edge at several points on the surrounding level country. The outlines of the depression, however, can be traced continuously with the exception of these few breaks, where its rim has been overtopped by the recent lava. It is nearly every where a vertical cliff, descending abruptly from the level or rolling plain. The southern end of the depression, which is not filled by the lavas of Masaya, is occupied by the waters of lake Masaya. The lake has a crescentic form and is bordered on the convex side by the vertical cliffs of the caldera wall rising 360 or more feet above its surface. On the concave side it is bordered by the gentle slope of the lavas of Masaya. It appears almost certain, therefore, that a portion of the volcanic plateau and perhaps a volcanic cone of considerable hight have disappeared by engulfment; but that a subsequent eruption at the saine point has partially filled the depression, building up a new cone over the same vent, though not to so great a hight as the former one. This new cone is Masaya. It has the rather low dome shape characteristic of cones composed largely of lava flows, and is broadly truncated by a double crater. A similar engulfment has occurred south of Masaya, forming the present lake Apoya. The depression did not coincide with a volcanic cone, but occurred on the northern side of mount Catrina, a low ash cone, carrying down one side of the latter and a portion of the adjacent plain. The depression is somewhat smaller than the one occupied by the lake and volcano Masaya, being about 4 miles in its largest diameter and nearly circular. The depression is now occupied by the waters of lake Apoya, which are 260 feet below the lowest 
point of the surrounding rim and about 1,500 feet below the highest point of the rim. This highest point probably coincides very nearly with the former volcanic peak, although the latter, being composed almost entirely of unconsolidated ash, has been very much reduced in hight by erosion. Several other caldera lakes of this type occur in the vicinity of Managua.

Volcanic plateaus.- Reference has been made to a plateau lying southwest of lake Managua and the northern end of lake Nicaragua, which I have called the Jinotepe plateau, from the principal town on it. This plateau is composed entirely of recently ejected volcanic material, chiefly a partially consolidated volcanic tuff, which was spread out probably in the form of a semi-liquid mud. The plateau has an altitude along its northeastern margin of 1,200 to 1,800 feet. From this gently undulating summit it descends gradually south and southwest to its margin against the older rocks to the south and to the Pacific coast. The central portion of the plateau has been but little modified by erosion, and probably preserves very nearly its original constructional form. This is due largely to the porous nature of the volcanic ash of which the surface is composed. The rain waters sink into the ground before they have an opportunity to collect into. sufficient volume to effect any modification of the surface, except where the original slopes were very steep. A belt along the coast, however, has been rather deeply dissected by stream channels, where the smaller intermittent tributaries are collected into permanent trunk streams and where the plateau has a decided seaward slope. Toward the north and northeast the plateau is terminated by a somewhat abrupt escarpment, which separates it from the lower plain of Leon and from the plain lying between lakes Managua and Nicaragua. These lower plains have precisely the same origin as the Jinotepe plateau, and it is quite possible that at one time the lower and higher plains may have been continuous, but were subsequently separated by a depression of the region to the northeast. In other words, the escarpment which limits the Jinotepe plateau to the north and east may possibly mark the line of a rather recent fault. The escarpment has been deeply scored by stream channels, so that it does not now have the characteristic form of a recent fault scarp, but the character of the materials of which it is composed is such that it would be rapidly modified, and so retain its original form but a short time.

\section{Climate}

GENERAL CHARACTER

The climatic conditions prevailing in this region have so direct a bearing on its geology and physiography that a brief statement of the more important characteristics of the climate is essential. Lying only $10 \mathrm{de}$ - 
grees north of the equator, the climate of the region is tropical, frost being entirely unknown. Furthermore, since it forms a narrow belt between two oceans, its climate is also insular, the annual range of temperature being very much smaller than all continental areas experience.

\section{AMOUNT AND DISTRIBUTION OFF RAINFALL}

Throughout the greater part of the year the trade winds prevail with fairly constant direction and force. These winds are probably deflected slightly to the north by the high volcanic range of Costa Rica, and to the south by the mountains of central and northern Nicaragua. The low gap across the isthmus constituting the Nicaraguan depression thus receives considerably more wind than would be due to the normal trades. It is probably this congestion of the air currents that causes the exceptional precipitation of this region. Coming from the warm Caribbean sea, the trade winds are saturated with moisture, and, as they strike the slightly elevated land forming the isthmus, the precipitation is there very abundant. Within the zone of maximum precipitation, which embraces the coastal plain and the adjacent hills, forming a belt from 50 to 100 miles wide, the annual rainfall reaches nearly 300 inches. Beyond this belt, at increasing distances from the Caribbean coast, it decreases very rapidly, and in the western part of the region the annual rainfall is less than a third of that on the eastern coast.

More important, however, than the absolute amount of rainfall is its distribution throughout the year. The isthmus may be divided into two distinct and well marked subdivisions by a line coinciding approximately with the present divide between lake and Caribbean drainage and crossing the San Juan near the point where that river leaves the lake. In the eastern division the rain is distributed with tolerable uniformity throughout the entire year. There are some years in which little rain falls for a period of three or four weeks in August and September, but this scarcely constitutes a dry season. In the western division, on the other hand, there is a distinct dry season of five or six months, in which there is practically no rainfall. The rain begins about the middle of May, when the trade winds become less constant, and an occasional storm comes from the northwest.

\section{PH YSIOGRA PHIC EFFECTS}

Eastern division.-These climatic differences between the eastern and western portions of the region give rise directly to very striking differences in vegetation, and, either directly or indirectly, to differences in the appearance and structure of the soils, in the topographic forms of the land surface, and in the effectiveness of various physiographic processes. 
The eastern division, in which the rain is distributed with tolerable uniformity throughout the year, is covered with a dense tropical forest. The only breaks in this forest are the stream channels and the open lagoons, or those so recently silted up that the soil is not sufficiently firm to support large trees. Throughout this region there are no human habitations, except in the few small towns along the coast and an occasional hut in a clearing on the banks of the rivers. There are no roads or other means of intercourse except by way of the streams.

The most directly apparent effect of the forest is to protect the land surface from erosion. The falling rain is intercepted by the canopy of foliage, and filters down gradually to the surface, where the smaller vegetation consists largely of palms, whose broad leaves afford a still further protection, so that the soil never receives the direct impact of the raindrops. Since there are no forest fires, the surface is more or less perfectly covered with forest litter, which acts as a further protective covering to the soil.

The character of the soil will be described more fully in treating of the regolith, but it may be stated here that the surface of this eastern division, wherever it rises above the level floodplains of the streams, is composed of a tenacious red clay. This clay never becomes dry enough to be intersected by shrinkage cracks, and is, of course, never loosened by the action of frost. Although it is penetrated by roots and to some extent by the burrows of insects, it nevertheless resists degradation to a remarkable degree. It was often observed that during a heavy rainfall, the water flowing from the steep hillsides would be scarcely at all discolored by sediment.

After a careful study of the region it was concluded that the absence of frost more than counterbalances the enormous rainfall, and that degradation of the surface is, on the whole, slower than in temperate regions, where the rainfall is less than a quarter of that in Nicaragua, but where the surface soil is thoroughly loosened by the action of frost.

Many of the small brooks which carry water throughout the year and have very steep gradient flow in shallow channels cut in this clay. The clay often forms cascades, and appears to offer more resistance to corrasion than many varieties of rock. Although the hill slopes are steep, they are comparatively smooth, not deeply gullied, as is usually the case in temperate regions, and it is only after the water has collected in considerable volume that it is able to lower its channel through the clay to the underlying rock.

A further effect of the vegetation, and hence indirectly of the climate, is that many of the streams are filled with an abundant growth of vege- 
tation, by which their current is checked and their effectiveness as an eroding agent correspondingly reduced.

The decay of vegetable matter is so rapid that there are no considerable accumulations of such matter either in the forest generally or in the lagoons and swamps. In boring through the alluvial floodplains, many of which have once been open lagoons, while an occasional log was encountered, nothing was found in the nature of peat, and the silt contains only a relatively small proportion of finely comminuted organic matter. On well drained surfaces, such as moderately steep hillsides, there is generally no humus layer. The red soil, practically free from incorporated organic matter, forms the surface, only in part covered by the forest litter.

Western division.-In the western division, particularly that portion of it lying west of the lake, the distribution of the rainfall produces a distinctly different type of vegetation. This region is characterized by open savannas, in which the trees are small and grow in isolated patches, the greater part of the surface being open and covered with grass or small bushes. These savannas are probably due to deforesting, in part by clearing for cultivation and grazing, and in part by fires. Wherever a forest covers the surface its character is entirely different from that in the eastern division. It has the thorny habit and scant foliage which characterizes the vegetation of a semi-arid region. The light is not cut off by the foliage of the higher trees, and hence the smaller herbaceous vegetation is much more abundant than in the eastern division. Fires prevail in the dry season, so that the forest litter does not accumulate, and at the beginning of the wet season, before the vegetation is renewed, the surface is entirely unprotected from the effects of the heavy rainfall which inaugurates that season.

Red soil is rarely seen west of the lake, the prevailing colors being blue, bluish gray, or black, and this is quite independent of the character of the rock from which it is derived, since the rocks are essentially the same as those which yield red soils in the eastern division. Toward the end of the dry season the surface is intersected by many deep cracks, often 2 or 3 inches wide and as many feet deep, which effectually destroy the coherence of the clay. 'This alternate saturation and baking of the soil therefore effects somewhat the same result as that accomplished elsewhere by frost. It also permits the incorporation of much organic matter with the upper portions of the soil, forming an exceptionally thick humus layer. From these and perhaps other conditions it results that the smaller rainfall of the western division is a very much more efficient agent of erosion than the greater rainfall of the eastern division. 
The effect of these climatic conditions is seen in the topography which characterizes the region west of the lake. The hills are extremely steep and deeply gullied. At the mouth of each ravine there is an alluvial cone, showing that a heavy load of coarse and fine detritus is moved by the occasional flood which the ravine carries.

The depth of the residual material, the regolith, is also very much less on the west side than it is on the east. This is doubtless due in part to the fact that the conditions of rock weathering are less favorable in the former than in the latter region, but it is also due in part to the more favorable conditions under which the agents of degradation act. Both of these factors, however, are directly dependent on climate.

Another factor which on the west side may be effective in modifying topographic forms is wind erosion. During the dry season, when the protecting vegetation has been removed by forest fires, the steady force of the trade winds raises clouds of dust, and the total amount of transportation effected by this agency must be very considerable. The effects are most noticeable on the lake and ocean beaches, where the sand is driven with great force and piled up in dunes. Roads on which there is sufficient travel to keep down the vegetation are usually sunk below the surface of the adjacent country. The track is often bordered by a vertical bank from 5 to 15 feet high, and a part of this erosion is doubtless due to wind action.

\section{Rock Formations}

\section{CONDITIONS FOR STUDY}

The geology of the region under consideration has been examined in detail only in the vicinity of the route of the proposed canal. Even where studied most carefully, the relations of the various rock formations are extremely obscure. This obscurity arises chiefly from the nature of the exposures which must be depended on in making out these relations. East of the lake, rock exposures are very infrequent, and it is practically impossible from them alone to determine the relations of the various rock formations. The vegetation is so abundant that no distant views can be obtained, and the information which can usually be derived from a broad study of the topggraphy is entirely wanting. The extreme depths to which the rocks are decayed and the uniform mantle of red clay which covers their outcrops effectually conceal their distribution and relations. The larger streams, as already explained, are chiefly flowing in old valleys which they are now silting up. Since they are not corrading their beds, their channels furnish exposures of materials other than alluvial only where they happen to impinge on the adjoining 



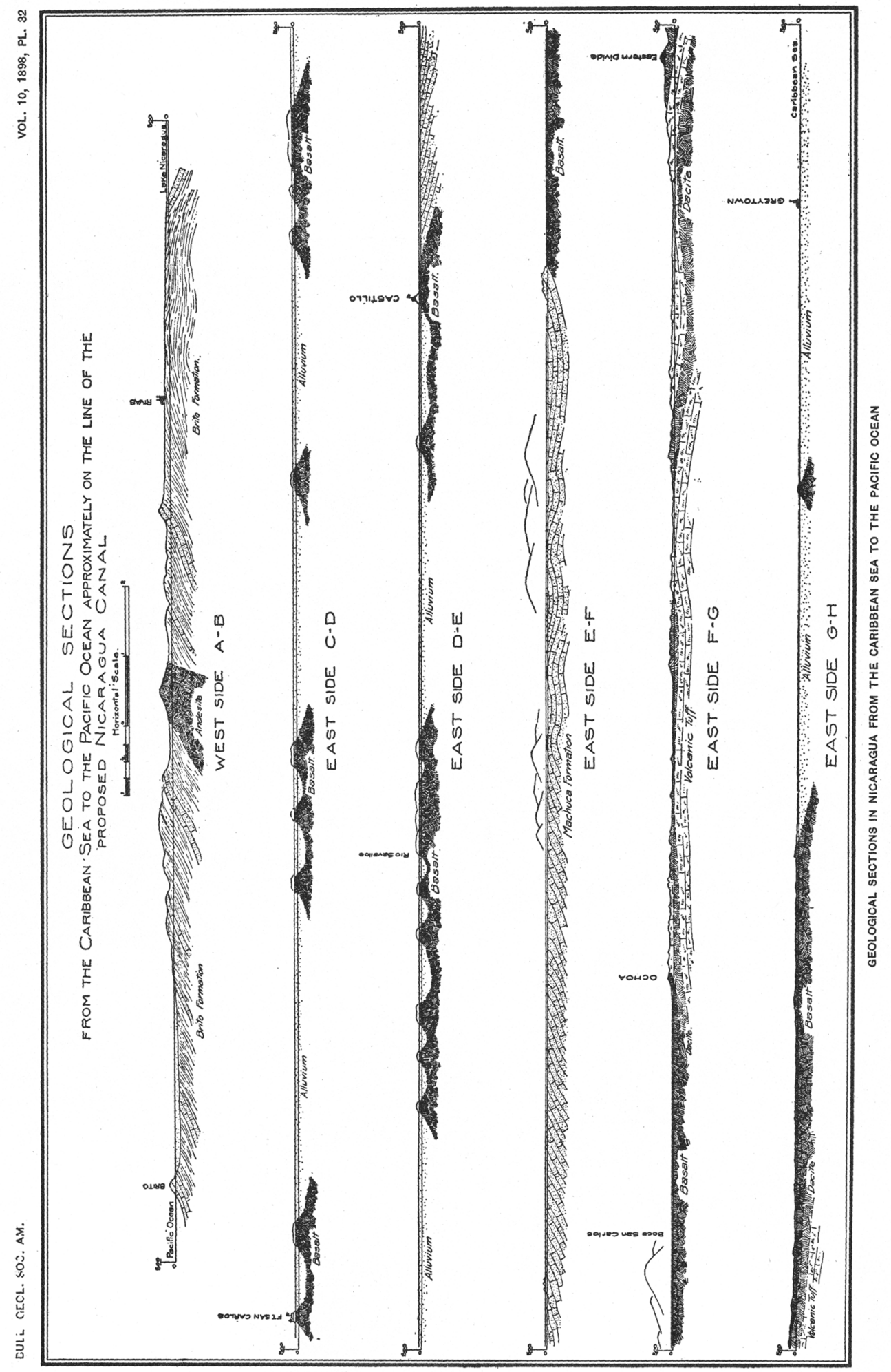


hills in their broad meanders. The only exception to this general statement is the San Juan river between Castillo and Machuca. The conditions west of lake Nicaragua are somewhat more favorable. The vegetation is not so abundant, and the removal of the residual matter has more nearly kept pace with the rock decay; also the slopes are more abrupt, and most of the streams are corrading their channels, except in the lower portions of their valleys.

\section{CLASSIFICATION OF THE ROCKS}

The rocks of the region are placed in two groups-Tertiary and postTertiary. Each includes both igneous and sedimentary formations. No rocks certainly older than the Tertiary occur along the line of the canal, although such have been reported from northern Nicaragua and also from 'central Costa Rica. The Tertiary sedimentary formations include the Brito and Machuca.

\section{BRITO FORMATION}

Distribution.-With the exception of a few areas of intrusive igneous rocks, the strip of land between lake Nicaragua and the Pacific is occupied entirely by the Brito sandstone. It extends from the Sapoa river to a point opposite the island of Zapatera. Remnants of the formation are also found along the lake shore to the southeast of Sapoa, and its present outcrops may extend continuously eastward to the area occupied by the Machuca sandstone. To the southward the formation is probably covered by the recent lavas of the Costa Rican volcanoes. It also probably extends some distance to the northwest of Zapatera, where it is covered by the recent tuffs which form the Jinotepe plateau.

Lithologic character.-The formation presents considerable variety in its lithological composition, but it has not yet been sufficiently studied to permit of its subdivision, even if this may be eventually possible. Much the larger mass of the formation consists of somewhat calcareous non-fissile shale. When fresh this is bluish gray and weathers to a yellowish or brownish color.

Distributed through the shale are numerous beds of sandstone. These are also somewhat calcareous and doubtless contain a considerable proportion of volcanic ash. The sandstone beds vary in thickness from a few inches to two or three feet, and occur singly or in groups. The latter are sufficiently heavy to materially affect the topography in some places. These sandstones, like the shales, are blue when entirely fresh, but are always weathered at the surface to some shade of yellow or brown. The hills immediately west of Rivas, rising abruptly above the Rivas plain, are due chiefly to the presence of these resistant sandstones. They occur 
most abundantly, however, near the Pacific coast, and are well exposed in the headland northwest of the Rio Grande valley at Brito. The beds here have a general, though somewhat variable, dip to the southwest; hence the higher portions of the formation make the cliffs along the Pacific. This seems also to be its most variable portion.

In addition to the shales which constitute its greatest bulk to the eastward, it here contains also beds of sandstone, conglomerate, and coarse volcanic breccia on the one hand, and on the other marly beds and lenses of pure limestone. Forming a part of the headland south of Brito is a bed of limestone something over 100 feet in thickness. Small outcrops of this bed, or one very similar, have been noted at several other localities to the eastward in the divide hills. Its limited extent is due in part to erosion, since the dip of the bed would carry it above the tops of most of the hills to the eastward, but it is doubtful if its original extension was very great. Several of the limestone outcrops noted are probably small lenses in the shale and not connected with the more continuous bed at Brito. A portion of this limestone has a peculiar concretionary structure, some of the concretions attaining a diameter of an inch and a half while other portions of the bed are oolitic.

Immediately west of this exposure of limestone, forming a group of islets nearly covered by high tide, is a very coarse volcanic conglomerate or breccia. The larger fragments are a foot or more in diameter and quite angular, and from this extreme they grade downward to small pebbles, some of which are well rounded. The present relations indicate that the conglomerate is the stratigraphical equivalent of the limestone, replacing it within a few yards. In some places the two rocks are seen to merge, the limestone containing numerous angular fragments of volcanic rock. At other points along the coast both north and south of Brito similar conglomerates occur. 'Their bedding is extremely irregular, and they afford evidence of having been formed rapidly and near the source from which their constituents were derived. While it is possible that the source of this material may have been to the eastward, it seems much more likely that it came from volcanic vents to the southwest-from volcanoes which have been entirely removed by the waves of the Pacific.

Although their connection has not been continuously traced, it is assumed that the sedimentary rocks found at various points along the southern margin of the lake east of Sapoa belong to the Brito formation. This region was examined by coasting along the lake shore, so that it was chiefly the rocks forming the projecting headlands which were observed. These consist almost entirely of sandstones very similar in appearance to the sandstones found interbedded with the Brito shales, and 
also conglomerates and breccias similar to those occurring at various points along the Pacific coast.

Structure.-The Brito formation, wherever observed, was found to be intersected by numerous joint planes. In some places these occur as two well developed sets of approximately parallel planes, which intersect each other nearly at right angles. In others the joint planes are very numerous and irregular, cutting the beds in all directions. The latter form is less common and appears to be confined to rather narrow zones where shearing and faulting has probably taken place. The frequency of the joint planes varies with the thickness of the beds. The rhomboidal blocks into which the beds of shale and sandstone are broken usually have diameters approximately equal-that is, the more massive the original beds the farther apart are the intersecting joint planes. These joints have permitted the percolations of surface waters to great depths and have facilitated the deep weathering which is generally observed. The weathering proceeding outward from the joints has resulted in the formation of concentric layers about a core, which coincides with the center of the original rhomboidal block. The resulting rounded blocks in some places give the appearance of a rude rubble wall. In the vicinity of Las Lajas the horizontal sandstone beds have been lain bare by the action of the waves, and where the rhomboidal blocks produced by jointing have been rounded by concentric weathering the appearance is that of a cobble pavement:

The Brito formation has suffered only a moderate amount of disturbance since its beds were deposited. Where its rocks are best exposed along the Pacific coast, numerous small faults are observed, the displacement in most cases being but a few inches. The inclination of the beds is generally under 20 degrees, though in a few localities the disturbance has been much greater and the dips increase up to the vertical. Neglecting these minor irregularities, the dominant structure is a broad anticline whose axis extends in a northwest-southeast direction approximately parallel with the Pacific and lake shores and a short distance southwest of the latter, where the beds are approximately horizontal. The greater portion of the region between the lake and the Pacific, therefore, is occupied by the western limb of the anticline and has prevailing southwest dips. From San Jorge to Lajas the dips are somewhat variable, but generally to the northeast. The greater part of the eastern limb of the anticline is covered by the lake. The numerous exposures of the Brito formation along the southern margin of the lake from the Sapoa to the Rio Orosi belong to this eastern limb of the anticline, and the beds have northeasterly dips of 5 to 30 degrees. The strike of these beds is not strictly parallel with that of the beds on the Pacific coast. They con- 
verge slightly toward the northwest, indicating a pitch of the anticline in that direction.

'The exposures of the Brito formation are so infrequent and the dips are so variable that no satisfactory measure of the thickness of the formation can be obtained. Taking the observed dips between the Pacific coast and the lake shore, the thickness exposed is estimated at upward of 10,000 feet. This, of course, is not the total thickness of the formation, since the bottom is not exposed at the axis of the anticline; also, the formation has undoubtedly suffered an unknown but considerable diminution in thickness by erosion, and there are no data for determining the thickness of strata which have been removed from the highest beds now observed.

Age of the formation.-The greater part of the Brito formation is apparently barren of organic remains. The only locations at which fossils have been found are on or near the Pacific coast. This, however, may be due to the fact that the rock exposures are not elsewhere of such a character as to facilitate the discovery of fossils, and the latter may possibly be more generally distributed than present knowledge would indicate. The fossils are confined almost wholly to the limestones and marly beds. They consist of corals, molluscan and foraminiferal remains. The latter are especially abundant. The rather meager collections have been submitted to Dr Dall for determination. He pronounces them Oligocene, and probably identical with the foraminiferal beds described by Hill from the Caribbean coast at Panama. One of the most abundant forms is a small numulite, Orbitoides, probably forbesei, which is characteristic of the lower Oligocene. The molluscan remains were collected on the Pacific coast, about 75 miles north west of Brito, in what was supposed to be a higher portion of the same formation. Dr Dall states that these have the upper Oligocene aspect, though there are not enough of them to be conclusive. He thus confirms the view entertained in the field, that successively higher beds in the Brito formation are exposed along the coast toward the northwest.

In addition to the fossils on which is based the above conclusion concerning the age of the Brito formation, it also contains rather abundant plant remains. They are in the form of driftwood and coal, but as yet no remains sufficiently well preserved for identification have been discovered.

Associated with the coarser sandstones are numerous blocks of wood, whose rounded forms suggest that they are fragments of drift which were incorporated with the sand and gravel while it was accumulating. In some cases they still contain a large proportion of their original carbon, and in others this has been more or less perfectly replaced by silica or iron pyrites. The coal occurs associated with the finer sediments, and, 
although a careful search was made, the thickest seam observed was under half an inch. While sufficient carbonaceous matter is sometimes disseminated through the shales to give them a black color, no indications were found pointing to the existence of workable coal deposits in the region examined.

Coal in workable quantity has been reported from the region southwest of the lake, between the lake shore and the Costa Rican volcanoes. The exact locality is on the Rio Hacienda, 12 miles from its mouth. It was not visited and no samples of the coal were seen, so that the report lacks verification. There appears to be no reason, however, why conditions favorable for coal accumulation should not have prevailed in some portions of this region during the deposition of the Brito beds.

\section{MACHUCA FORMATION}

Distribution.- -The immediate margins of the San Juan valley from the lake eastward to Castillo are, so far as known, composed entirely of igneous rocks. From a point a few miles below Castillo to another midway between Machuca and the Boca San Carlos the rocks are largely sedimentary, although they contain some igneous, rocks in the form of small dikes. These sedimentary rocks constitute the Machuca formation. Its present extent is known only in the immediate vicinity of the river. The region south of the upper San Juan, forming the lower valleys of the Frio and Poco Sol, is geologically unexplored. It is therefore possible that the Machuca formation may extend westward through this region and be nearly, if not quite, continuous with the outcrops of the Brito formation south of the lake. Until this connection is established, however, the original continuity of the two formations is a matter of doubt.

Lithologic charaster.-The rock exposures in this region to the eastward of Castillo are very much less satisfactory than those along the Pacific coast; hence the character of the Machuca formation is not so well known as is that of the Brito. Like the latter, it appears to consist chiefly of calcareous shales, with which sandstones are interbedded. The constituents of the rocks are largely igneous in their origin, but there are no coarse conglomerates or breccias such as occur in the Brito.

No pure limestones or distinctly marly beds have been discovered, although the examination of the formation has not been sufficiently exhaustive to enable one to say that such beds do not occur.

Structure.-The exposures are comparatively few in which the dip of the Machuca sandstones can be determined. At the Cano Bartola the dip is about 15 degrees and to the north. At Machuca it is 20 degrees 
and to the northwest. These dips suggest the presence of a synclinal basin, the southern end of which is crossed by the San Juan. They are not sufficient, however, to locate its axis. Although in general the dips are light, the formation has suffered considerable local disturbance. Breccias, probably due to faulting, have been observed at several points, the best example being the ledge which projects into the river opposite the mouth of the Machuca; also numerous sharp folds occur in the vicinity of Machuca. The same evidence of faulting and folding would probably be found elsewhere if the exposures were sufficiently abundant to render the structure determinable.

The rocks of the Machuca formation are generally found deeply weathered. The weathering is hastened by the igneous constituents which they contain, and the final product is a residual red clay, which is indistinguishable from the product of the decay of igneous rocks. Except for the fresh rock obtained beneath the residual mantle by means of the diamond drill, it would have been impossible to determine even approximately the limits of the sedimentary and igneous rocks. At some points, as at Machuca, the sandstone contains a very large proportion of iron pyrites, which by oxidation also tends to hasten its decay.

Nearly everywhere the beds are intersected by numerous joint planes, the only marked exception being the rather massive interbedded_sandstones exposed on Machuca creek. Weathering has proceeded inward from the joints toward the centers of the rhomboidal blocks, producing concentric shells about a central nucleus exactly as in the Brito formation.

Age of the formation.-No fossils have yet been found in the Machuca formation which are sufficiently well preserved for specific determination. At Cruzita, one mile below Machuca, the core from the diamond-drill hole in the bed of the river contains numerous indistinct organic forms. The rock is described by Dr Ransome as an andesitic tuff containing fragments of limestone. The organic forms are revealed by the weathering of the rock with the removal of the soluble limestone, and they are also shown in the thin-section under the microscope. While they can not be identified they strongly suggest the forms which occur so abundantly in portions of the Brito formation. The beds in which they occur are evidently derived in large part from fresh volcanic tuff, though the latter was not so abundant as to prevent the growth of organisms in the sea in which it was being deposited.

In the absence of conclusive fossil evidence, therefore, the age of the Machuca formation, so far as it may be determined, rests on other and less satisfactory evidence. It is believed to be nearly or quite contemporaneous with the Brito formation-that is, Oligocene (Tertiary). The grounds on which this conclusion is based are briefly as follows: (1) 
There is a general similarity in lithologic composition and appearance between the two formations. (2) Both have suffered about the same amount of deformation, elevation, and erosion since they were deposited. The value of this fact for correlation depends on the proximity of the areas which they occupy and the evidence that the recent geologic conditions have been similar in both. (3) Both formations bear about the same relation to a group of igneous rocks, which was in part contemporary with them and in part subsequently invaded their beds. The differences in composition of these intrusive rocks are not greater than differences in igneous rocks within the same area, which are known to be nearly or quite contemporaneous. (4) Finally, as pointed out above, it is quite possible and even probable that the two formations are nearly or quite continuous through the southern part of the upper San Juan valley.

In the vicinity of the Toro rapids, some distance westward from the present limit of the Machuca formation, a few siliceous boulders have been found which contain fossil remains. The original location of the beds from which these boulders are derived is not known, though they have probably not been transported a great distance. These fossils are unfortunately only casts. They have been examined by Dr Dall, who says they "are not determinable, but have the general look of a freshwater assembly." They are not regarded, however, as having any special bearing on the age of the Machuca, since it is by no means certain that they have been derived from that formation.

\section{TERTIARY IGNEOUS ROCKS*}

Location and general character.-As stated above, the beds of the Machuca formation occupy a broad belt, which crosses the valley of the San Juan, extending from a point a little below Castillo eastward some distance beyond Machuca. While this formation contains a considerable proportion of volcanic material and is intersected by numerous dikes, it contains no lava flows and no beds the constituents of which are exclusively of volcanic origin. In the remainder of the country between the lake and the Caribbean, wherever the underlying rocks or their residual products rise above the recent alluvium of the floodplains, the rocks are almost entirely of volcanic origin. They present a great variety in structure and appearance, varying through the extreme types of volcanic products from distinctly stratified beds of fine volcanic ash, through well rounded conglomerates, fine and coarse angular breccias,

* The writer is indebted to Dr F. L. Ransome, of the U. S. Geological Survey, for a petrographic examination of the igneous rocks collected in Nicaragua and determination of the rock species. 
surface lava flows, and intrusive masses of rather coarsely holocrystalline rock which did not reach the surface before cooling.

Massive igneous rocks. -The principal varieties of igneous rocks which are found between the lake and the Caribbean are augite andesite, olivine basalt, hypersthene basalt, and dacite. Of these four varieties the first three are very similar in appearance, and can not ordinarily be distinguished with certainty in the field. They are dark bluish gray to black in color, generally fine grained, but often containing certain minerals, as olivine and feldspar, which can be readily distinguished with the unaided eye. They are generally compact and heavy, though a well marked vesicular structure characterizes some portions of the basalt. 'The red clay which is the final product of their decay contains numerous residual boulders of the fresh rock covered with a thin ochreous crust.

The dacite is light gray in color, and is made up of abundant quartz and feldspar crystals embedded in a fine grained or glassy, gray groundmass. It is lighter than the trap rocks, and is considerably softer even when entirely unweathered. The dacite contains numerous fragments of darker basic rocks. It doubtless reached its present position as a lava flow, and these inclusions are fragments of the underlying rock which were picked up and incorporated in the molten mass during its passage through the lower formations to the surface. Many of them are a soft greenish rock exactly like the tuff on which the dacite rests. The presence of these included fragments of a different rock is doubtless the reason the dacite was called conglomerate in the Canal company's eastern divide sections. Of the fragmental igneous rocks two classes may be made, according as their igneous or sedimentary characteristics are the more prominent. In the first class are included the tuffs which form the western portion of the eastern divide, passing under the dacite at an angle of about 5 degrees. This tuff is related to a basic lava, either andesite or basalt. It has a dark greenish color and very fine grain. It is soft and talcose, and on exposure to the air the cores generally crumble into small fragments. While this tuff owes its kaolin-like character to the decomposition of a basic glass, it was probably never a hard rock. The pressure to which it has been subjected since its deposition has apparently not been sufficient to produce complete induration.

The extent to whieh these rocks have weathered has been already pointed out, but may be referred to again in explanation of the difficulty which has been experienced in determining the relations of the various members of the volcanic formations. All weather to a red clay, and exposures which afford any indication of the original character of the under- 
lying rock are extremely infrequent. The chief reliance must be placed on the occasional residual boulders, on the presence or absence of quartz grains in the clay, and on the occasional cut banks along the streams. The large scale sections of the proposed damsites indicate the complexity of the relations between the various volcanic formations and the hopelessiness of attempting to work out these relations from surface indications alone without the aid of sections derived from drilling. For the reasons given above it is practically impossible to map the surface outcrops of these various rock varieties. Their distribution can only be indicated in a general way.

The rock forming the hill on which San Carlos is located consists of augite-andesite. This extends eastward down the river to the Rio Melchorita, forming the hills which rise above the level alluvial plains. At Palo de Arco occurs olivine basalt, and this rock continues eastward a short distance beyond Castillo. At the Sabalos it presents an amygdaloidal phase, and in the hill near the mouth of the Santa Cruz it consists of a very coarse breccia. The high hills at the junction of the San Carlos with the San Juan consist of hypersthene basalt. This is a holocrystalline rock, and one which probably cooled at some distance below the surface. It may possibly mark the center of eruption from which lavas in the surrounding region, which have a similar composition but less perfect crystalline structure, were derived. A similar but less crystalline rock also occurs in the hills on the north side of the San Juan river. To the eastward, at Ochoa, the hypersthene basalt occurs south of the river, while the rocks at the river bank on both sides and extending to the northward are olivine basalts. This olivine basalt extends eastward beyond the San Francisco hills. At the 'Tamborgrande it is replaced for a short distance by dacite; then in the Tamborcito hills by hypersthene basalt, but again comes in in the Sarapiqui hills, and thence extends east, forming all of the hills which border the lower portion of the San Juan river, and also those about Silico lake. The dacite, while it does not reach the surface at Ochoa, was encountered there in boring. It was also found at lower Ochoa, beneath a bed of volcanic tuff or breccia and some unconsolidated sediments. It comes to the surface at Tamborgrande, and it probably continues north in the high ridge connecting the Tamborgrande hills with the eastern divide. It forms the surface through the higher portion of the eastern divide, overlying andesitic tuffs and passing under basalt.

Fragmental igneous rocks.-Since the closely related fragmental rocks, both the bedded tuffs and the conglomerates, do not weather in such a way as to furnish residual boulders, their presence is much more diffi-. 
cult to detect. From the character of the exposures in the bluffs along the San Juan river, and from the results of the drill sections, it seems probable, however, that the bulk of these fragmental rocks is as great or greater than that of the massive rocks. About 4 miles above the Boca San Carlos these beds are exposed in a high bluff on the north bank of the river. There is shown a considerable diversity in the character of the material, varying from the finest tuff to coarse rounded conglomerate. All parts of the beds are equally weathered, forming a tough clay quite free from grit. The different beds vary considerably in color, although the prevailing colors consist of various shades of red and brown. The planes of stratification between the different beds are not sharply marked, and the indications are that the deposit was made rather rapidly and in the presence of strong currents. Similar exposures of thoroughly decayed sedimentary beds occur in the river bluffs at various points between Ochoa and the mouth of the San Francisco.

It is probable that during the extrusion of the volcanic rocks in this region numerous bodies of water were formed by the interruption of drainage lines by the lava flows. In these bodies of standing water the finer tuffs were accumulated with considerable regularity in their planes of stratification. Forests were present on the adjoining shores and much vegetable matter was accumulated along with these silts. There thus resulted deposits of considerable depth, such as those encountered at Lower Ochoa. 'These were subsequently covered by lavas or deposits of fragmental material, but have never been buried sufficiently deep to bring about their complete consolidation.

In some places conditions were favorable for the deposition of calcareous material. In the section at the San Francisco a bed of very fine grained earthy limestone about 3 feet in thickness was encountered with fine tuff above and below. The limestone was perhaps originally a calcareous mud which has been thoroughly solidified and is now comparatively hard. The adjacent tuffs, both above and below, may have been solidified at one time, but are now soft and talcose. No traces of organisms can be detected in this limestone, and it may have been precipitated from solution without the intervention of life. In the railroad cut near Silico lake there occurs a bed of clay enclosing water-worn pebbles and numerous fragments of wood which is immediately overlain by a flow of basaltic lava. This clay was doubtless alluvial or accumulated in a lake and has probably not been buried to a sufficient depth to produce consolidation.

The beds of lava and volcanic tuff above described have been but little changed from the position in which they were originally deposited. Wherever bedding planes can be detected in the stratified tuffs they are 
practically horizontal. The planes separating lava flows generally have a decided original inclination, and this may be increased or diminished by subsequent tilting. In the sections of the apper and lower Ochoa damsites (plate 31) the planes separating the several formations have a slight dip to the northeast. The same thing is observed in the sections of the San Francisco embankment line and of the Eastern divide. In so far as these dips are due to deformation, they suggest the presence of a low anticline to the east of the Machuca basin, its axis approximately parallel with the Caribbean coast and crossing the San Juan near the Boca San Carlos. For reasons given above the structure of these igneous formations, as well as of the Machuca sandstone shown on the geological sections (plate 32), rests on a very few observations and should not be accepted with too great confidence.

\section{RECENT ALLUVIAL FORMATIONS}

The post-Tertiary formations of the region include the recent deposits which make up the floodplains of the rivers and the deltaplains about their mouths, together with the products of the recent volcanic activity.

The character of the alluvium has been somewhat fully described on a previous page and requires but little fixrther mention. It varies in character with the local conditions under which it is deposited and with the character of the rocks from which it is derived. On the west side, filling the valley of the Rio Grande, it consists of fine brown sand and clay, derived from the decay chiefly of the sandstones of the Brito formation. In some places it contains enough calcareous cement, which has been deposited by infiltration from above, to give the allurium a fair degree of coherence.

In the valley of the San Juan there is considerably wider diversity in the character of the alluvium. In the upper portion of the valley it consists of fine blue clay interbedded with fine blue and brown sand. The sand occurs chiefly in the river channel and is the residuum which the sluggish current of the river has been unable to transport. It is probable that but little sand would be encountered in the alluvium at any considerable distance from the present channel.

In the lower portion of the valley the alluvium in the immediate vicinity of the river contains considerable black sand, such as it is at present transporting in great volume. This occurs either disseminated through the finer silt which is derived from the decay of rocks in the adjoining region or it occurs as distinct layers interstratified with the clay. The presence of a considerable proportion of sand in the silt renders it much firmer than when the latter consists chiefly of clay. The 
sand does not extend to any great distance from the present river channel, and hence the silt becomes less stable with increasing distance from the river.

The material which fills the tributary valleys, such as the Danta, the San Francisco, the Cureño, and the Tamborcito, is a fine silt, generally quite free from grit, with a blue color, and containing abundant fragments of wood and leaves. When this material is thoroughly drained it becomes fairly compact, as shown in the vertical banks of most of the streams, but at some distance from these streams, where the drainage is imperfect, it is quite soft to a great depth.

This alluvial silt or mud when first exposed sometimes has a brilliant blue color, which quickly changes to a yellowish brown on exposure to the air. The change in the color takes place at the exposed surfaces within a few minutes.

The material forming the deltaplain of the San Juan is similar to that composing its floodplains. The black sand is carried out to sea and transported along the shore by littoral currents and thrown up to some distance above tidelevel by the waves, so that within a belt two or three miles broad along the coast the surface is composed chiefly of black' sand, with a small amount of vegetable mold. The fine silt increases in thickness from a feather-edge at its outer margin at a rate somewhat greater than the eastward slope of the deltaplain.

It is probable that the delta has always been fringed by a belt of sand which never rose more than a few feet above sealevel. The region, however, has been sinking while the delta was forming. As the delta grew by accretions of sand to its outer margin, the corresponding growth on its surface was made by the fine silt deposited from the flood waters of the rivers. The plane separating the sand from the overlying silt thus appears to have a gentle landward inclination, being slightly above sealevel at the present coast and some distance below sealevel toward its inner margin.

\section{RECENT VOLCANIC ROCKS}

The vulcanism which gave rise to the igneous rocks associated with the Tertiary sediments appears to have become entirely extinct in this region, and doubtless a long interval elapsed in which it was free from any manifestations of volcanic activity. In comparatively recent times the vulcanism was renewed and its products form the Costa Rican and Nicaraguan volcanic ranges; which have already been described. Its products also form the Jinotepe plateau and the plain of Leon, which extend northwest from the Lakes to the Pacific. 
In mineralogic composition these recent volcanic products consist very largely of hypersthene-andesite. The last eruption from Masaya was a basaltic lava, and a comparatively recent lava flow from Ometepe is also a basalt. With these two exceptions the recent activity, so far as observed, has given rise only to andesitic lavas and tuffs. The cone of Ometepe consists largely of lapili, with occasional interlaminated lava flows. The lapili consist in about equal parts of black or gray pumice and of black glassy rock, which has been thoroughly shattered and ground up by explosive eruptions. The tuffs from this volcano, which have been carried to a considerable distance from the center of eruption chiefly by wind, are composed more largely of tuffaceous material.

The materials erupted from the other volcanic centers forming the various peaks of the Nicaraguan range appear to be similar in composition to those found in Ometepe. The Jinotepe plateau is composed largely, if not altogether, of volcanic tuffs, which probably reached their present position in the form of a more or less fluid mud. This mud becomes solidified, but never sufficiently so to form hard rock. It is quarried in many places and used as a building stone. It can be readily cut out with a pick, but becomes somewhat harder on exposure to the air. The rock fragments which constituted this tuff vary widely in size, from large boulders several feet in diameter to the finest dust. They are all angular, and in this respect they differ from the volcanic conglomerates associated with the Tertiary rocks of the San Juan valley. A further difference is the almost complete absence of stratification and sorting of the rock constituents. This tuff appears to have been sufficiently fluid to flow on rather low slopes, and the present southward and westward slopes of the Jinotepe plateau are probably the original constructional slopes.

In the vicinity of Managua planes separating successive mud flows intersect the rock and are utilized in quarrying. In these quarries human tracks have been found in the rock, where they were made while it was still in the form of mud. They prove the recency of the tuffs and indicate something as to its physical condition when first deposited. At the margin of this plateau the tuff is found filling the valleys in the older formations and smoothing out the former irregularities of the topography. In many cases the present streams nave in part reëxcavated the old valleys, though not to their original width.

The vertical cliffs surrounding the caldera lakes, Apoya and Masaya, display the underlying structure of this plateau near the centers from which its material was derived. These cliffs are composed of alternating layers of tuff and solid lava flows. It is impossible to say how far from the centers of eruption these lava flows extend, but the distance is 
probably not very great. Near the centers of eruption the character of the tuff is somewhat different from that at greater distances. It is less homogeneous in character and frequently consists of sharply defined alternating tuff beds which differ widely in appearance. In the bluffs surrounding lake Apoya this is well shown. Numerous distinct bands of white pumice occur interbedded with dark lapili and fragmental rocks, and these in turn are interbedded with the lava flows.

\section{Rock DecaY}

\section{IMPORTANCE OF THE SUBJECT}

One of the features which first impresses the geologist or the engineer in Nicaragua is the extent to which the surface rocks are weathered. 'This feature is common to all tropical regions, at least to those in which there is an abundant rainfall. While the extent of rock weathering has an important bearing on the geology of the country, and thus a high degree of scientific interest, it is a fact of prime importance to the engineer in planning any structures in this region. It enters directly into the cost of excavation and also into the cost and permanence of foundations for all heavy structures.

\section{CONDITIONS FA VORING ROCK DECAY}

General discussion of the subject.-It has been shown by various investigators that the conditions most favorable to rapid rock decay, and hence to the accumulation of an extensive mantle of residual materials, are high temperature and abundant moisture. These conditions are only indirectly responsible for a large part of the rapid rock decay which always accompanies them. They are also the conditions on which the rapid growth and decay of a luxuriant vegetation depends, and it is the latter process which is chiefly instrumental in hastening the process of rock weathering.

It is manifest that heat alone, without moisture, does not give rise to conditions which favor rock decay,for it is a common observation in desert regions, where the temperatures reach the maximum, that the rocks are disintegrated to a limited depth by the alternate expansion and contraction due to changes in temperature, but that rock decay is practically absent. On the other hand, abundant moisture and continuous low temperature do not give conditions favorable for rock decay, since these conditions favor the accumulation of ice and snow. Glaciers are effective instruments for transportation of rock debris and to a limited extent are efficient as eroding agents, but practically no rock weathering goes on in their presence. 
Even where the moisture is abundant and the temperature is sufficiently high for the growth of an abundant vegetation, unless the conditions are also favorable for the decay of that vegetation they are not favorable for rock weathering. This is seen in the extremely luxuriant forests of the North Pacific coast, where the successive generations of forests grow on the remains of their predecessors. The conditions are here favorable for the preservation of vegetable remains in the form of peat, and rock decay is practically absent. It appears, therefore, that an essential condition for rapid rock weathering is the rapid decay of abundant vegetable matter, and this leads to the conclusion that the most efficient factor in the weathering process is the presence of the complex organic acids which are derived from the decay of vegetation.

Effect of chemical composition.-The depth to which the rock decay has gone and the character of the products depends in a considerable measure on the chemical composition of the rock, on its original structure, and on the subsequent alterations which it has undergone, such as fracturing in the process of consolidation or by subsequent dynamic disturbances.

But few rocks are found in this region which are not either wholly or in large part composed of material of volcanic origin; hence their chemical composition does not present so wide a range as is usually found among sedimentary and igneous rocks. A few are apparently the products of thermal springs, and the composition of these is perhaps the best suited of any to resist the process of rock decay. Examples of rocks of this origin are found in the small hill opposite San Francisco, a short distance east of the lake, and also at Chorrera, on the Aguas Muertas. These are composed chiefly of silica, which is the mineral least acted on by the processes to which rock decay is chiefly due.

The Machuca sandstone, as already explained, contains a large proportion of feldspathic minerals, as well as iron sulphide and carbonate of lime; hence it is peculiarly susceptible to hydration, oxidation, and solution.

The igneous rocks belong to the basic and intermediate classes, and hence contain a large proportion of the lime-soda feldspars and the ferromagnesium minerals. Both of these groups of minerals are especially liable to alteration. Quartz, on the other hand, is relatively scarce. There are in the region no quartzites and argillites, the two classes of rocks which are especially indifferent to the action of the weathering processes.

Certain beds associated with the lavas are composed of fine volcanic ash, in which the constituent particles had never acquired a crystalline structure, but were entirely glassy. These are perhaps the most readily altered rocks in the region, and wherever they have been encountered, 
even as in the eastern division, at very great depths beneath the thick sheet of dacite, they are found in the form of a soft, soapy or talcose rock.

The rocks of the Brito formation contain a much smaller proportion of igneous constituents than any of those in the eastern division; hence they are in a measure free from this source of weakness. They contain, however, a large proportion of lime carbonate, and in them the weathering process consists chipfly in the solution and leaching out of this cementing material. In most of these rocks the lime forms so small a proportion of the entire mass that the bulk is not diminished or the structure altered by its removal. The rock merely changes in color from bluish gray to brown or yellow, and at the same time it becomes soft and porous.

Effect of original structure.-The original structure of many of the rocks is such as to facilitate weathering to a considerable degree. This is especially true of the basalts, which are largely composed of surface lava flows and have the vesicular structure which is characteristic of such flows.

In many cases it is observed that the degree of weathering in the case of basalts varies directly with the extent of the vesicular structure. The upper and lower surfaces of the flows which were rapidly cooled by contact with the underlying rocks and by exposure to the air contain more or less abundant gas bubbles, while their central portions are relatively compact. In such cases it is found that the vesicular portions are thoroughly weathered, while the interior compact portion contains large boulders of fresh rock or continuous beds of the same. The dacite, which, so far as observed, never has the vesicular structure of the basalt, does not show these striking differences in the degree to which its different portions have weathered.

The depth of weathering in the volcanic sandstones and conglomerates naturally depends largely on the original structure of their constituents, which shows considerable variation. Thus the conglomerate encountered at upper Ochoa is composed chiefly of pebbles of compact, fine grained basalt, and is weathered only, to a moderate depth. A conglomerate was encountered at low er Ochoa similar to the above, except that its constituent pebbles are largely composed of vesicular or pumicious basalt. This difference in the composition of the pebbles is accompanied by a corresponding difference in the depth of weathering, which has extended to a very great depth in case of the latter rock.

Effect of secondary structures.-A third important factor in determining the depth to which rock decay has gone is the extent to which the rocks have been affected by dynamic agencies with the production of secondary structures, such as folds, faults, and joint planes. Of these effects joint- 
ing is perhaps the most important. It pervades nearly all the rocks of the region, both igneous and sedimentary. The joints which intersect the igneous rocks are perhaps largely due to shrinkage on cooling. The regular prismatic jointing common in basaltic lava flows has not been observed in this region. In its stead is a system of more or less regular joints which divides the rock into large rhomboidal blocks. The less basic rocks, such as the dacite and the volcanic conglomerates, are nearly or quite free from these joints, and the manner in which they weather is therefore quite different from that of the basalt.

The sedimentary formations are generally very deeply fractured. In these the joints are doubtless due to the action of dynamic forces, which, while they have not greatly changed the original position of the beds, have been sufficient to thoroughly shatter them to great depths. Only a few of the more massive beds of sandstone have in some measure escaped this general fracturing. Its effect is most pronounced in the less massive portions of the Brito formation. At the surface the joints have been enlarged by the weathering process, and the rock consists of a loose mass of small fragments. This condition prevails to a depth of more than 100 feet from the surface, as shown by the boring at La Flor. In some cases it was observed that the cracks which intersected the rocks had subsequently been healed up by the deposition of calcite. This, however, is not general at ordinary depths.

A direct consequence of the presence of these cracks intersecting the rocks is the development of secondary concentric structures. The cracks permit the percolation to great depths of surface waters bearing the agents which are most active in rock decay. The weathering proceeds outward from these joints with the production of successive concentric layers about a central nucleus. The concentric structures which have already been described were thus produced.

\section{ROCK DECAY IN THE EASTERN DIVISION}

As has been already pointed out, there is a marked difference in the distribution of the rainfall on opposite sides of the isthmus, with a corresponding difference in the character of the vegetation and in the extent and products of rock decay. It will be necessary, therefore, to consider the process and the products in the two divisions of the isthmus separately.

The eastern division is characterized by a heavy rainfall, so distributed throughout the year that there is no well marked dry season; hence the surface soil is never permitted to become dry and the forest litter is never removed by fires. The entire surface is covered with a dense XLVII-BuLr. Grol. Soc. AM., Vor. 10, 1898 
inantle of vegetation. This consists of a heavy forest growth, except. where the land surface has been so recently reclaimed from swamps and lagoons that it has not yet been invaded by the forest, or that its surface is not sufficiently firm to support forest trees. Even where the forest does not extend, the smaller vegetation is extremely dense and the surface is even more effectually protected than under the forest. It may be stated in general, however, that all of the land which rises above the margins of the extensive floodplains and the silt-filled valleys-that is, all which is underlain by rocks older than the recent silt-is forest clad. The canopy of foliage formed by the treetops is so perfect that much of the light and all of the direct sunlight is intercepted; hence the smaller vegetation at the surface is not exceptionally luxuriant and only partially covers the surface.

The forest trees of this region are nearly all deciduous, but the season of shedding their foliage is different for different species; hence there is a continuous supply of forest litter throughout the entire year, and its decay not being checked by frost is a continuous process.

All rocks of this eastern division show the effects of weathering to great depth, not only the igneous but the sedimentary rocks as well. In the course-of the drilling operations which were carried on in this region a large amount of data was obtdined concerning the depth to which decay has gone in rocks of various origin and composition, and also the products of the weathering.

\section{PRODUCTS OF ROCK DECAY}

Classes in general.-The final product of rock decay in this region is a red clay. This represents the complete oxidation of all the constituent minerals of the rock except the quartz, and the complete obliteration of the original rock structure. From this extreme the products of rock decay present all possible gradations to the perfectly fresh rock. While there are no sharp lines of demarkation between different phases of the rock weathering, the products may be conveniently though somewhat arbitrarily separated into three groups, namely, red clay, blue clay, and soft rock. The first two differ chiefly in the degree of oxidation, and the second differs from the third chiefly in the extent to which the original structure of the rock has been obliterated. The third group itself is not sharply separated from the fresh rock, but passes into it in most cases by imperceptible gradations.

Red clay.-As already stated, in the eastern division of the region under discussion all portions of the surface which rise above the margins of the alluvial floodplains are covered with red clay-the final product of rock decay. 
Its appearance and doubtless also its composition vary somewhat from place to place. 'The bright red is varied by shades of yellow, brown, and occasionally olive green, but the prevailing tint is nevertheless very generally red. The abrupt change in color between the residual clay and the adjacent alluvial clay is very striking. The latter is never red, but is always some shade of gray or blue. The only essential difference between the two clays is in the form of their iron. In the alluvium this is in the ferrous state, forming light colored compounds. In the residual clay it is in the ferric state, and not only more highly oxidized, but the oxide is in large measure dehydrated, giving the bright red color of hematite.

The cause of this difference in the state of oxidation in clays which appear to be affected by the same conditions is doubtless the different amounts of organic matter incorporated with them.

As already described, the residual clay is very compact. It is never loosened by frost or by shrinkage cracks. The only means by which vegetable matter finds its way below the surface is by growing roots and insect burrows. The amount thus introduced is not sufficient to materially affect the chemical conditions within the zone of rock decay. The vegetable matter at the surface is so rapidly and thoroughly oxidized that the organic compounds which result from the process are not effective reducing agents when they percolate downward in contact with the red clay, but probably carry an excess of oxygen which is expended in the oxidation of the rock constituents below. In the alluvium, on the other hand, the vegetable matter while only rarely constituting a large proportion of the mass, is thoroughly disseminated through it, and controls the chemical conditions preventing the oxidation of ferrous compounds and reducing ferric compounds to the lower state of oxidation. Before the deposition of the alluvium which now fills the valleys of the region the bottoms of these valleys were covered with residual clay the same as that now covering the hills. This clay underlying the alluvium and subjected to the constant downward percolation of the reducing solutions from the latter has generally though not always lost its red color. It is often found to be mottled with blue patches where the reducing solution has gained access to the ferric oxide.

Doubtless the proportion of silica, alumina, and iron depend to some extent on the composition of the rock from which the clay was derived, but this variation is not sufficient to produce marked differences in its appearance and physical properties. The depth of this upper division is not very great, usually from 10 to 30 feet. The separation between the red clay and the underlying blue clay is usually rather sharp, although in many cases there is a band of mottled clay between the two. 
Blue clay.-This division is usually somewhat thicker than the overlying red clay. While its prevailing color is blue, it varies from white to various shades of yellow and brown, depending largely upon the original composition of the rock from which it is derived. It represents the zone of complete rock decay and disintegration but incomplete oxidation. The blue color is due not to the presence of a reducing agent, but to the absence of a sufficient oxidizing agent to convert the iron into the higher oxides. It generally contains more or less abundant fragments of thoroughly weathered rock, which retain their original structure, and where it is derived from basalt it usually contains numerous boulders of fresh rock, the nucleii about which concentric weathering has taken place. The lower limit of the blue clay division is often more indefinite than its upper limit. By an increase in the number and size of the rock fragments, both fresh and weathered,it passes into the zone of soft rock. As will be readily seen, the point at which the division should be drawn is, to a large extent, arbitrary, since the distinction is at best only one of degree.

Soft rock (saprolite).-The red clay retains but few of the characteristics of the rock from which it was derived; hence it is fairly uniform throughout the region. In the blue clay, also, the original character of the rock is almost entirely obliterated, and it is therefore somewhat uniform. In case of the soft rock, however, in so far as it retains the original structure of the rock from which it was derived, it presents the same diversity as the hard rocks of the region. In some cases this division is wanting, and the blue clay extends entirely down to the fresh rock. This is the case with the Machuca sandstone. In other cases the blue clay is thin or absent, and there is a great thickness of soft rock. This is usually the case with the dacite.

The material classed as soft rock represents the zone of practically complete rock weathering, but of incomplete rock disintegration. The forms of the constituent minerals can usually be made out in rocks which were originally coarse grained. The original structure is generally well preserved. In the vesicular lavas the gas cavities are nearly as perfect as in the hard rock. In the volcanic conglomerates and breccias the distinction of matrix and inclosed pebbles or angular fragments is perfectly sharp, yet all the material included in this class can be crumbled in the fingers.

The extensive beds of fine basaltic and andesitic tuff which occur in the Eastern divide and elsewhere are perhaps the most easily altered rocks in the region. 'There is some doubt as to their ever having been thoroughly consolidated, and this may account for the depth to which they are weathered. Wherever found, even under a great mass of com- 
pact, fresh dacite, the tuffs are soft and talcose, resembling a very compact, structureless clay. The principal alteration which the material appears to have undergone is hydration. It can be easily cut with a knife, and on exposure to the air it rapidly crumbles. This material has not been placed in the class with the soft rock, although it might properly be so classed. Since the classification shown on the sections was made with a view to its practical application to engineering problems, the upper limit of hard rock does not generally correspond with the limit of rock weathering from the surface downward. The rock classed as hard usually shows more or less alteration of its constituent minerals, but not enough to affect their coherence. While this incomplete weathering does not materially affect the excavation of the rock, it becomes very important and should be carefully considered when the rock is intended for use in construction. Rock which appears to be perfectly fresh when first removed from the quarry often contains many incipient fractures, and these develop rapidly on exposure. It is probable that all of the tuff and a considerable proportion of the dacite in the Eastern Divide cut would develop this weakness on exposure, and hence would be entirely unsuited for structural purposes.

\section{ROCK DECA Y IN THE WESTERN DIVISION}

Turning now to the western division, the phenomena of rock decay are found to be strikingly different, and, as already pointed out, this probably depends largely on climatic differences which prevail on opposite sides of the isthmus. The most striking difference is the almost complete absence of red color in the surface soils. This change in color coincides so exactly with the change in climatic conditions that it is difficult to escape the conclusion that the change in color is due directly to climatic causes. The prevailing color in the surface soil in the,region west of the lake is a bluish gray, varying to black. It is sometimes a yellowish gray and very rarely red. One reason suggested for the absence of the complete oxidation of the surface soil and the consequent red color is the greater amount of vegetable matter which becomes incorporated with the upper layers of the soil. As pointed out in the discussion of the climate, the surface soil is alternately baked and saturated with water. The numerous cracks which form during the dry season collect leaves and twigs and when the cracks are closed by the moisten. ing of the soil this regetable matter is thoroughly incorporated with the clay to a very considerable depth. It may be that it is present in sufficient quantity to combine with all the oxygen which is carried down by the percolating waters and thus prevent the oxidation of the iron con- 
tained in the underlying rocks. This reducing action of the contained vegetable matter prevents the oxidation of the iron in the alluvial silts in the eastern division, and there seems no reason why it should not be equally effective in preventing oxidation in the residual clays in the western division.

Another difference at once noted is the extent to which rock decay has extended. The opportunities for determining the extent of rock weathering on the west side have not been so good as for determining its extent in the eastern division, and the rocks which are there present do not afford the same variety in composition and structure. Observations are confined practically to two kinds of rock, namely, the igneous basic rock forming the large area north of the Rio Grand valley, and the rocks of the Brito formation. The basic igneous rocks do not differ essentially from those which occur on the east side, where they are covered with a great depth of red and blue clays. On the west side, however, the residual material covering them consists of a comparatively thin layer of bluish gray clay. It is somewhat doubtful whether the thinness of this residual mantle is due to the less rapid decay of the rock or to the more rapid removal of the products of weathering. Certainly the latter factor is important, but the rate of weathering may also be very much slower under the climatic conditions which here prevail than in the eastern division. The blue clay appears to constitute practically the only product of decay, and the extensive zone of soft rock in which the minerals are entirely altered, but in which the original rock structure remains, is wanting.

The clay derived from the decay of the Brito formation is quite similar to that derived from the igneous rocks, except that it contains a notable amount of sand where it is derived from the more sandy portions of the formation. Where derived from the calcareous shales, it furms a blue or black tenacious, plastic clay. Its depth varies from nothing up to 10 or 15 feet, depending on the position in which it occurs. The greatest thickness is found in the level valleys, where the surface is practically at baselevel, and where the surface erosion is very nearly reduced to zero. On the steep hillsides, on the other hand, the same kinds of rocks are covered with a very scanty layer of residual soil or it may be entirely wanting.

So far as known, there is nothing on the west side which corresponds to the zone of soft rock generally represented in the sections from the eastern division. Wherever opportunity was afforded for observing the character of the passage from the overlying blue clay to the underlying igneous rocks, the transition was found to be abrupt, and the intermediate zone of weathered rock was absent. 
Overlying the shales of the Brito formation, there is a zone of weathered rock which corresponds in some measure with the zone of soft rock generally observed in the eastern division. Within this zone the beds are thoroughly shattered by the presence of numerous joint planes, and concentric weathering has been more or less extensively developed. The mechanical alterations'which the rocks have suffered, however, are much more important and striking than the chemical changes; hence in the sections this is ealled the zone of disintegrated rather than weathered rock.

\section{Recent geological History}

RELATIONSHIP BETWEEN TOPOGRAPHY AND GEOLOGY

The relation between the topography and the recent geological history of the region is so intimate that a description of the former necessarily involves some statements concerning the latter. The same is to a somewhat less extent true of the lithology; hence in the foregoing description of the topography and of the rock formations some of the main features of the geological history have been briefly outlined. With these prerequisite facts of topography and lithology, the geological history may now be taken up systematically and in some detail.

CONDITIONS ANTERIOR TO TERTIARY TIME

As already indicated, no rocks older than the Tertiary occur in the region of the Nicaraguan depression, so that there is only negative evidence as to the conditions which prevailed here during geological periods earlier than the Tertiary.

In the region to the northward in northern Nicaragua the occurrence of granites and crystalline schists has been described; also small areas of Paleozoic rocks. The present extent of these older formations, however, as well as their former distribution, is not known.

The region to the south in Costa Rica also contains older formations, but they are almost completely covered by the recent volcanic rocks, so that the former extent of the land in this direction also is unknown. It is quite possible that a depression of this portion of the isthmus occurred at the beginning of Tertiary time, and that a somewhat extensive land area was wholly submerged or converted into an archipelago.

\section{EARLY TERTIARY DEPOSITION AND VOLCANIC ACTIVITY}

As indicated in the description of the Brito and Machuca formations, these rocks were deposited on the sea bottom in early Tertiary time. It is assumed that during their deposition there was open communication 
between the Atlantic and the Pacific oceans across this portion of the isthmus, although it will be readily conceded that this conclusion is merely an hypothesis. Sedimentary formations have not as yet been traced entirely across the isthmus, and there is no other direct evidence by which this hypothesis can be proven. If, however, there had been any land separating the two oceans, its rocks ought to be recognizable at the present time as distinctly older than the Tertiary sediments or the volcanic rocks which are intimately associated with them. As already stated, no such older rocks are recognized in the region of the Nicaraguan depression, and, although the volcanic activity which was contemporaneous with the deposition of the sedimentary formations may have cut off the communication between the two oceans early in Tertiary time, it appears at least probable that at the beginning of that period, and perhaps through the Oligocene, the sea had free access across the isthmus.

The argument for the hypothesis of free communication across the isthmus in Tertiary time has been very fully made by Hill.* A single link, but a very important one, is wanting in the evidence obtained at Panama. This missing link in the evidence is supplied by the discovery of sedimentary beds on the Pacific coast of Nicaragua containing the same fossils as the beds previously found on the Caribbean side of the isthmus. Supplementing Hill's argument with this new evidence, therefore, the case seems to be definitely settled.

The conditions which prevailed during the deposition of the sedimentary rocks were somewhat shallow seas, with an abundant supply of sediment alternating between sand and mud. The sediment appears to have been chiefly derived not from a region anderlain by deeply decayed rocks, but rather from unconsolidated and recently ejected volcanic material. The extremely coarse conglomerates which occur in the Brito formation along the Pacific coast and on the southwest shore of lake Nicaragua point to the proximity of active volcanoes. The coarser material supplied by these volcanoes was transported but a short distance, and shows the effect of only a moderate amount of wear. The finer material was widely disseminated, and constitutes a very considerable proportion of the sedimentary formations. These contain, however, a certain proportion of clay, doubtless derived from the residual mantle covering the older rocks which formed adjacent land areas.

The conditions at certain points were favorable for the deposition of limestone. Considerable lime is disseminated throughout the entire Brito formation, and is segregated in marly beds and in occasional lenses of pure limestone. The volcanic activity not only furnished a large portion

* Robert T. Hill : The geological History of the Isthmus of Panama and portions of Costa Rica. Bull. Mus. Comp. Zool., vol. xxviii, 1898. 
of the material of which the sedimentary rocks are composed, but it continued for some time after their deposition, and produced numerous dikes, cutting the beds, and also extensive lava flows, which in places rest upon them. This volcanic activity appears to have been much more violent and long continued near the axis of the present isthmus than on the west side.

The region between lake Nicaragua and the Pacific ocean, as already indicated, is occupied chiefly by sedimentary beds and by recent volcanic material. Only a few large areas and occasional dikes of intrusive rocks have been found associated with the Brito formation, and it is not certain that these ever reached the surface. While the coarse conglomerates along the Pacific coast demonstrate the near proximity of volcanoes, the indications are that the volcanic vents from which this material was derived were to the west of the present coastline.

The conglomerates are confined, so far as known, to the immediate margin of the ocean, and the source of the material seems clearly to have been to the westward. The similar conglomerates which occur on the southwest shore of the lake appear to have been derived from vents to the southward, and to mark the southern margin of the sea in which the Brito formation was deposited.

As stated above, the Tertiary volcanic activity was most prevalent in the region east of the lake. More than two-thirds of the area which has been examined between the lake and the Caribbean is now occupied by igneous rocks, which present considerable variety in composition and structure. It is probable that the present area of the Machuca formation does not represent its original extent, but merely a region in which the volcanic rocks have failed to wholly conceal the sediments.

The numerous beds of conglomerate and stratified ash associated with the lavas in the region eastward from Machuca point to the presence of standing water during the period of volcanic activity. This water in which the ejecta were deposited may have been a shallow sea, from whose bed the volcanoes rose, or a series of lakes formed on the imperfectly drained constructional surface. It is very difficult, however, to determine even approximately the conditions which prevailed during the deposition of this heterogeneous collection of formations. The difficulty is of course greatly enhanced by the deeply weathered condition in which the rocks are now found.

\section{MIDDLE TERTIARY UPLIFT AND EROSION}

The period of deposition in this region appears to have been termiinated toward Middle Tertiary time by an uplift which was coincident 
with a suspension of the volcanic activity. The extent of the land after the uplift can only be determined in a very general way. It is probable that the Pacific coast was some distance farther southwest than at present, and there may have been volcanic peaks along this coast which have subsequently been entirely removed by marine erosion. The isthmus was very likely somewhat broader than now, although the elevation was such that any particular rock stratum was from 100 to 200 feet lower than at the present time. The uplift inaugurated a period of active degradation. It is probable that the surface at the beginning of this period was in general broadly undulating, with perhaps isolated volcanic peaks, but no distinct mountain chain. The uplift was accompanied by only moderate warping and tilting of the surface, for the Tertiary beds have suffered comparatively little disturbance up to the present time. Their average dips are between 10 and 15 degrees. In general the character of the deformation was such as to produce a series of gentle folds, whose axes are approximately parallel with the coastlines. This was doubtless accompanied by more or less faulting, although evidence of the latter is very meager.

The character of the present drainage makes it evident that no structures were developed in the region sufficiently well defined and pronounced to have a marked influence on the direction of the drainage. The stream courses, with the exceptions which have been already noted and which will be explained later, are such as would have resulted from normal stream development on a low, gently undulating arch.

The region now occupied by the Nicaraguan depression appears to have been originally the lowest and narrowest portion of the isthmus; hence its surface was more nearly reduced to baselevel during this degradation period than that of the broader portion to the north. A somewhat perfect peneplain was developed along its margins, and broad baseleveled valleys were extended well back to the divide, in which there were numerous low broad gaps. Although the position of the coastlines at the beginning of this period is not easily determined, their position at its conclusion may be made out with a fair degree of probability. The Atlantic coast was perhaps about where it now is, or possibly a little farther east than at the present time, for although it has subsequently been moved westward by submergence and by marine erosion, it has also been considerably extended by emergence and by deposition, so that its oscillations have about balanced each other. TThe Pacific coast, on the other hand, differed materially in outline from the present. As already indicated, lakes Nicaragua and Managua then had no existence, and the coastline occupied a position somewhat near that represented on the accompanying outline map, plate 30 , although the line there shown 
is intended to represent the position of the coast at a somewhat later period.

\section{POST-TERTIARY ELEVATION AND GORGE CUTTING}

The middle and late Tertiary time, as indicated above, was occupied by a period of erosion, with the reduction of much of the region to the condition of a peneplain. In the late Tertiary or Pleistocene the region was again elevated, this time probably without deformation of its surface, although there may have been a slight arching of the isthmus on the northwest-southeast axis, and possibly also an arching on a subordinate axis west of the present lake basin. The total elevation was probably between 200 and 300 feet: The immediate effect of this uplift was to stimulate the streams to renewed activity. They began at once to trench the peneplain and the broad baseleveled valleys which they had formed in the preceding period.

The consequences of the uplift were necessarily first felt in the lower courses of the streams, and their valleys were there first lowered to the newly established baselevel. Thence the deepened channels were cut backward toward their headwaters. In the valley of the river which occupied the present position of the San Juan from Castillo eastward, various phases in the process of reduction were present. In the lower course of the stream a broad valley was developed with only a few isolated remnants of the former plain remaining. This extended upward as far as Tamborgrande. From Tamborgrande to the Boca San Carlos the valley was rather broad, but the adjacent hills retain distinct evidences of the former peneplain, and wherever the rocks were unusually hard the valley of the stream was correspondingly restricted. Between the Boca San Carlos and the Continental divide, which was then near the present position of Castillo, the stream was comparatively small and flowed in a narrow gorge. Its channel was cut down to a rather low gradient-backward to the present position of the Machuca rapids. At this point was the junction of three branches, probably of nearly equal size, occupying the valleys of the Infiernito, the Machuca, and the present San Juan.

The tributaries of this river also cut down into the old valleys, and the extent to which they succeeded in lowering their channels varied with their position and size. Naturally those nearest the mouth of the stream were earliest stimulated to renewed activity by the lowering of the trunk stream into which they flowed, and hence these had the longest time in which to effect the lowering of their own channels, while those nearer the headwaters of the trunk stream were not materially affected until late in the gradation period. Thus the tributaries of the San Juan 
as far up as the San Francisco have lowered their channels below their old baselevel-if not entirely to their headwaters, at least well back toward them. Beyond the San Francisco the upper portions of the tributaries are found still flowing at the level of their old valleys, which they have not as yet had time to completely dissect. Excellent examples of this immature drainage are seen in the basin of the Machado, and with increasing frequency from that point westward to the Toro rapids. Thus the Machuca and Bartola are rapid streams, still actively corrading their channels almost down to their junction with the San Juan.

The stream which occupied the upper portion of the San Juan valley, as indicated above, headed on the Continental divide in the vicinity of Castillo, and receiving as tribitaries the Rio Frio and other streams now emptying into the lower end of the lake, flowed northwest to the head of a bay in the vicinity of the island of Madera. This stream, like the other, was stimulated by the uplift and rapidly cut its channel back. ward, dissecting its old valleys well up toward the Continental divide. This old channel, now drowned by the waters of lake Nicaragua, has been traced more or less continuously from the vicinity of Madera southeast with gradually decreasing depth to the vicinity of the Balsillas islands. It may very likely have extended beyond this point, and its upper portion has been subsequently filled by the sediment carried into the southern end of the lake chiefly by the Rio Frio.

The cape which extended northwest between the waters of the Pacific ocean and the bay of Nicaragua appears to have suffered some differential uplift, its southern portion being elevated more than its northern portion. Not enough study has yet been given to the whole of this region, however, to determine with any degree of certainty the details of its recent history. Nevertheless it is known that the rivers to the south of the Rio Grande have cut their channels much deeper than those to the north, and that some of the latter appear to have been affected but little either by this uplift or by the subsequent depression. Only the valley of the Rio Grande has been carefully studied, and it is certain that the uplift there was at least 200 feet.

The active wave cutting. along the Pacific coast during this and the preceding period shortened the distance from the coast to the subordinate divide on the highland forming the cape, thus rendering the length of the streams flowing in opposite directions from this divide very unequal. Those flowing to the Pacific therefore had a very steep gradient, while those flowing east to the Nicaraguan depression had a comparatively flat slope; hence the corrasion of their channels was proportionately greater by the steams flowing directly to the Pacific than by those 
which reached the ocean indirectly through the bay of Nicaragua. The former group, of which the stream occupying the lower portion of the present Rio Grande valley is the best studied example, cut their valleys well down toward the new baselevel nearly up to the divide, while the inner portion of the peneplain occupied by the eastward flowing streams was scarcely at all affected and the gorge cutting was confined chiefly to their lower portions, which are now occupied by the waters of the lake. It is true the main trunk stream entering the head of the bay cut its channel backward well toward its headwaters, but the tributaries from the southwest cut only shallow trenches in the outer portion of the Rivas plain and none at all in its inner portion.

The relations of coast lines and divides which prevailed at this period are represented on the outline map (plate 30 ). The divide between the streams flowing to the Pacific and those flowing to the bay, which, after the bay had been converted into a lake, became the Continental divide, is shown by the broken line nearest the Pacific coast. The length of the streams flowing in opposite directions from this divide is seen to be very unequal. The inequality in length is so great that before the acceleration in corrasion could be felt half way up the courses of the longer eastflowing streams it had caused a deepening of the entire channels of the shorter Pacific streams. With such advantages, the shorter streams began an active conquest of drainage area from those less favorably located on the east of the divide. The result was that at one point, where the advantages of the Pacific stream were most decided, the divide between contending streams was pushed east, and successive portions of the eastern drainage were diverted to the Pacific.

The rapidity with which different portions of the divide were shifted east depended largely on its relative hight and the length of the contending streams. The conditions were evidently most favorable nearly opposite the end of the bay, probably because the soft sedimentary rocks here extended entirely across from the ocean to the bay, while to the north and south there were considerable areas of harder igneous rocks; hence the surface had here been well reduced in the preceding period, and was favorably circumstanced for further rapid reduction.

The stream which suffered diversion earliest appears to have occupied the present position of a portion of the Tola, the upper Rio Grande, the Guiscoyol, and the lower Lajas. This stream was probably 5 or 6 times the length of its opponent on the Pacific side, so that the same fall from the divide was distributed over a correspondingly greater distance, and hence had relatively much less than a fifth of the efficiency of the shorter stream. This east-flowing stream had in the preceding period developed a rather broad valley, the upper portion of which lay between the main 
divide and the hills bordering the Rivas plain. The remnants of this baseleveled valley are found in the upper Tola basin, while the lower portion of that basin is very perfectly reduced to the present baselevel, only the uniform summits of a few rounded hills suggesting the former existence of a plain at a higher level.

In the upper Rio Grande basin the Rivas plain can be traced from its typical development at the present Continental divide westward through the increasing degrees of dissection to the summits of a few hills nearly down to the Tola. The inference, therefore, that the remnants of the plain observed in the upper Tola and in the upper Rio Grande valleys

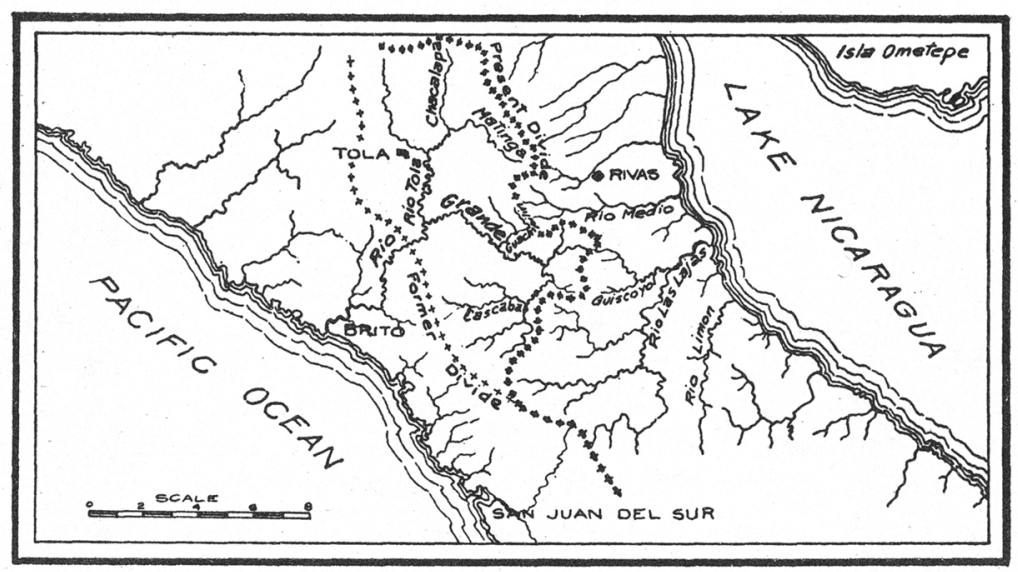

Figure 1.-Basins of the Rio Grande and Rio Las Lajas.

To illustrate recent shifting of Continental divide.

were originally portions of the same baseleveled plain, is fairly well established. Accelerated by the lowering of its outlet, the diverted Tola has itself made considerable progress in the conquest of drainage formerly belonging to the eastward flowing streams. It has diverted branches both of the Gonzales and Medio, the reversed streams now forming the Chacalapa and Matinga, and leaving low gaps in the present Continental divide. The Guachipilin, now flowing into the upper Rio Grande, formerly found an outlet eastward to the Medio.

The latest diversion has evidently been the Guiscoyol, which was perhaps the largest stream in this region flowing eastward. Its source, now forming the headwaters of the Rio Grande, was in the high hills which border the lower Rio Grande valley. The Rio Grande is thus seen to have a composite course, which now makes a nearly complete circuit before reaching the sea. 
The recently deserted gap between the diverted upper Rio Grande and the beheaded Guiscoyol is a broad shallow valley, its highest point being 154 feet above sealevel. It is occupied during the wet season by a swamp, from which the water appears to flow in both directions. That flowing toward the lake occupies a shallow channel, evidently once the bed of a larger stream, while that flowing west soon finds itself in a narrow, sharply cut ravine with rapid descent to the rather deep channel of the Rio Grande.

The process of diversion above outlined was inaugurated at the beginning of the high-level period now being considered, but it doubtless continued during the succeeding period after the formation of the lake. It is evident that the process is still going on, and that the Continental divide is now moving eastward at a rate which may be regarded as extremely rapid oompared with most drainage changes, and, with the decided advantages possessed by the Rio Grande, it is somewhat surprising that the latter stream has not already tapped the lake.

\section{RECENT DEPRESSION AND ALLUVIATION}

The process of gorge-cutting which characterized the period of high level just described was terminated by a depression of the region, amounting to a little more than half the elevation which had inaugurated the preceding period, The effect of the depression was to drown the lower portions of the river valleys, converting them into tidal estuaries. At first the depression affected only those portions of the river valleys which were brought below sealevel, while in the upper portions the deepening of the stream channels continued as actively as before. The waste from the land, however, instead of being carried out to sea and distributed by littoral currents, began at once to shoal and fill up the heads of the estuaries. With the consequent lengthening of the streams their beds were raised, and consequently the influence of the depression was extended up their valleys at a rate corresponding to the extension of their lower courses. It is probable that the depression of the surface was comparatively slow, and the filling of the estuaries may have very nearly kept pace with their formation. As soon, however, as the depression of the land was at any point slower than the filling of the estuary the influence of the depression would proceed upstream at a rate depending upon the extension of the lower course of the river.

The depression of the land appears to have been accompanied by a moderate local warping of the surface. This warping may have affectea the entire isthmus, but the means of detecting it are not at hand, except in the western portion. The Rivas plain has evidently suffered a gentle tilt to the northeast, and it is more than probable that this tilting was 
accomplished during the depression of the land surface. It will be recalled that the Rivas plain is a plain of degradation, formed by the action of streams flowing near baselevel. A plain formed in this way must necessarily be nearly horizontal, but the present Rivas plain has a slope to the northeast of about 8 feet to the mile. This is manifestly greater than the gradient of streams forming a baseleveled plain. It is considerably greater than the gradient of the present streams which cross it. The latter, emerging from rather deep, narrow gorges in the residual hills to the southwest, cut narrow channels in the inner portion of the Rivas plain. These channels in some cases have a depth of 60 feet or more. They gradually decrease in depth toward the outer margin of the plain, the unequal slopes of the stream bed and the peneplain surface bringing them together at the lake margin.

Accompanying the depression of the land which inaugurated this period was a renewal of the volcanic activity of the region. It is possible that the volcanism and the depression may be intimately related as cause and effect, or may be both the effects of a common cause. However this may be with regard to the depression of the region as a whole, it is more than probable that the observed deformation of the surface is due directly to the volcanic activity. This activity was manifested along two lines of vents forming the lines of volcanic craters whose topography has already been described. The southern series of vents forming the Costa Rican volcanic range broke out within a land area and possibly on a somewhat elevated plateau. These volcanoes have obliterated the preexistent topography and built up a massive mountain range. The northern series of vents forms the Nicaraguan volcanic range. Between the nearest peaks of the two ranges-Orosi to the south and Madera to the north-there is a gap of about 30 miles.

However closely the two ranges may be associated in the causes which led to the extension of their lavas and in the character of the lavas themselves, they are entirely distinct at the surface and are separated by sedimentary and igneous rocks belonging to an earlier geological period. As seen from the map (plate 30), on which the former position of the Pacific coastline is shown, the volcanic vents which formed the Nicaraguan range broke out on the sea bottom and extended nearly parallel to the west coast. The northern vents of the group were the more active, and have given rise to a somewhat continuous mountain chain and also to the extensive Jinotepe plateau.

FORMATION OF LAKE NICARAGUA

The position of these volcanic vents with reference to the coastline was such that when their ejected material had reached the surface of the sea 
it formed a barrier across the bay of Nicaragua. This barrier was built gradually higher by successive eruptions, and since in the area behind it precipitation was greater than evaporation, the waters rose above sealevel and doubtless escaped westward over the barrier during periods of quiescence in the volcanic activity. As the surface of the barrier was raised by successive additions of volcanic ejecta, the surface of the impounded waters was raised to a hight probably somewhat above the present elevation of lake Nicaragua. The lake thus formed occupied not only the position of the former bay, but flooded the basins of the tributary streams. Its surface finally reached the lowest point in the Continental divide, where a west-flowing stream headed against one which occupied the present position of the San Juan. When this point was reached the intermittent escape of the impounded waters across the volcanic dam to the westward was changed for a permanent outlet to the eastward.

The gap when first discovered and overtopped by the rising waters was doubtless of deeply weathered rock and residual clay. This must have been very rapidly cut down by the escaping waters until the underlying hard rock was reached, when the permanent level of the lake was established, which it has retained practically unchanged to the present time.

It is quite possible that the gaps through the Continental divide to the east and through the divide across the west strip of land between the former bay and the Pacific ocean were so near the same level that the lake had for a short time an outlet both to the Atlantic and to the Pacific.

An examination of a portion of the Rio Grande gorge possibly throws some light on this question. From the point where the Rio Grande turns abruptly to the northwest in the reversed channel of the stream which formerly flowed east, for a distance of 4 or 5 miles to the point where the gorge opens out to the alluvial plain bordering the lower river, there is an old channel which has been partially silted up by the present river. The stream only occasionally touches the rock walls of the gorge on the convex sides of its meanders. At the same time it nowhere departs wholly from the old channel-that is, it nowhere has the character of a superposed stream. It is evident that the present stream is smaller than one which excavated and formerly occupied this valley. There are three ways in which the present conditions might have been brought about:

1. The present valley might have been occupied by a stream which was once larger than at present, but which has suffered a partial diversion of its headwaters by capture through the encroachment of a neighboring stream. This possible explanation, however, is not applicable in this case, since the Rio Grande is itself a growing stream, and is constantly 
adding to its drainage area and hence to its volume by encroaching on the basins of its neighbors. There is no evidence from the arrangement of the drainage in this region that the Rio Grande has ever lost any territory in this way.

2. The former volume of the Rio Grande might have been greater by reason of different climatic conditions which at some former time gave the region a greater rainfall than it now has. There is no direct evidence in favor of this hypothesis. So far as known, there is no evidence whatever that the rainfall has ever been greater in this region than it is at the present time. On the contrary, if a greater rainfall has been the cause of the old valley, this condition would have been general in its effects, and all the streams of the region would show the same evidence of greater volume in the past. So far as known, however, the Rio Grande is exceptional in this respect.

3. The third possible explanation is that the lake may have found an outlet for a short time by way of the Rio Grande valley. As pointed out above, the lake rose behind the barrier formed of volcanic ejecta until the level of the impounded waters reached the lowest gap in the Continental divide, where they spilled over and escaped by way of a river channel leading eastward to the Caribbean sea. Now the material forming the gap in the divide must have been residual clay and deeply weathered rock, material which would be rather readily removed by the corrasion of the escaping waters; also a study of the present river gorge where the Continental divide formerly existed shows that the channel has here been considerably lowered. It does not seem at all improbable, therefore, that the lake for a short time may have been 50 or more feet higher than now with refrence to the surrounding country; but if it were raised 50 feet, its waters would escape by the Lajas-Grande gap westward to the Pacific. It seems possible that when the waters of the lake were first raised by the growing barrier to the northwest, they found two gaps at approximately the same altitude, and for a time escaped in part east to the Atlantic and in part west to the Pacific. Active corrasion of the two outlets began at once. The gorge of the Rio Grande was excavated, but the gap in the main divide in the east was at first in less resistant material, and was consequently cut down the more rapidly. By the time hard rock was reached in this gap the waters had been entirely withdrawn from the western outlet. The eastward tilting of the region west of the lake may have continued well into this period, and have been in some measure instrumental in finally turning the outlet to the east.

It is possible that at first the gap in the main divide to the east was so much higher than the one to the west that all the water escaped by 
the latter; that the backward cutting of the east-flowing stream lowered a gap in the divide, and by reason of the less resistant material of which it was composed diverted at first a part and finally all the waters of the lake to the east. This is only a modification of the third hypothesis, and does not affect the main point, namely, that for a longer or shorter period the lake had two outlets-one by the Lajas-Grande gap and the other by the valley of the present San Juan.

This modification of the hypothesis removes one of the most serious objections to the above stated theory for the origin of the lakes. An examination of the region which it assumes to have been occupied by the Continental divide leads to the conclusion that the lowest gap in the divide was probably more than 50 feet above the present river. An elevation for the present divide above the San Juan at Castillo of 100 feet or possibly more would accord better than an elevation of 50 feet or less with the topography and drainage of the region and with the characteristics of divides in general; and it is by no means impossible that the backward cutting of the eastward flowing stream should lower the gap 50 or 75 feet in residual clay while the outlet of the lake was cutting the 4 or 5 miles of rock gorge new occupied by the Rio Grande.

The above theory for the formation of lake Nicaragua is supported by a consideration of its fauna. In a paper on the fishes of the lake, Gill and Bransford make the following statements:*

"The element of especial interest in connection with the ichthyic fauna of the lake is the association of forms that we are in the habit of regarding as characteristically marine with those that are at least as exclusively fresh-water types. Thus with the species of Cichlids and Characinids, of which no representatives have been found in marine waters, we have a species of Megalops, a shark and a sawfish."

"The why and wherefore of such combinations of species are not entirely apparent. They may have resulted (1) from the intrusion of salt-water types into the fresh waters, or (2) from the detention and survival of the salt-water fishes in inlets of the sea that have become isolated and gradually become fresh-water lakes. On the whole, it appears more probable that the latter is the case. By the uplift of the land an inlet of the Pacific ocean might have been shut off from communication from the ocean, and the character of the water would be soon changed by the copious showers of that tropical country. The shark, sawfish, megalops, and other species mostly found in the sea had, however, time to accommodate themselves to the altered conditions, and in this connection it must be remembered, too, that most of the types in question are known to voluntarily ascend high up streams and even' into fresh water. The numerous rapids of the river discharging from the lake discourage, however, the idea that the species enumerated have voluntarily ascended that river and entered the lake."

Of special significance is the fact, not known at the time the above

*Theodore Gill and J. F. Bransford : Synopsis of the Fishes of Lake Nicaragua. Proc. Acad. Nat. Sci., Philadelphia, vol. xxix, 1877, p. 179. 
was written, but recently communicated to the writer by Dr Gill, that the sharks of lake Nicaragua are specifically identical with those found in adjacent portions of the Pacific ocean, but distinct from those found in the Caribbean sea.

\section{SUBSEQUENT MODIFICATION OF THE LAKE}

Volcanic eruptions. - The original outline of the lake formed behind the barrier of volcanic ejecta was probably quite different from that of the present lakes. The subsequent modification has been due to several agencies. The continuation of volcanic eruptions has doubtless very much contracted the northwest portion of the depression. It is probable that the original depression was occupied by a single lake which extended northwestward beyond the present limits of lake Managua. Later eruptions encroached on this portion of the lake basin, and finally a flood of volcanic ash and mud was carried entirely across the depression, forming a barrier which cut off the upper portion of the lake, raising its surface between 30 and 40 feet above the surface of the larger portion to the southeast. The strip of land separating the two lakes is a nearly perfect plain composed of partially consolidated volcanic tuff.

The Tipitapa river, which forms the outlet of lake Managua, crossing this barrier, has cut its channel backward nearly to the upper lake. It falls about 13 feet within less than half a mile of the point where it emerges from lake Managua. In a very short time, therefore, unless the backward cutting of this stream is arrested, the level of lake Managua will be lowered to the extent of 13 feet.

The original outline of lake Nicaragua has been further slightly modified by the recent volcanic eruptions in the vicinity of Madera and Ometepe, and perhaps also of Mombacho. The northeast side of the latter volcano appears to have suffered an enormous landslide, which has pushed before it a great mass of earth and rock. This now has a peculiar hummocky surface and forms a long point projecting into the lake and a large number of small islands.

Wave cutting.-The outline of the lake has further been modified by the action of the waves. The trade winds produce a nearly constant surf on its west side, and this has accomplished considerable erosion at certain points. The wave action has probably cut a shelf into the adjoining plain entirely around this portion of the lake, the extent of the shelf depending on the character of the rocks which were encountered by the waves.

In the region south of Madera bold headlands are formed by masses of hard igneous rocks which tend to protect the less resistant rocks between. 
At some points the steeply inclined sedimentary rocks contain certain beds of sandstone which are much more resistant than the mass of the formation, and these form parallel ledges which extend into the waters of the lake in some cases a mile or more, the softer rocks between having been removed by the wave action to a considerable depth.

Some estimate may be made as to the extent of the wave-cut terrace along the lake shore west of Ometepe from the hight of the cliff. The Rivas plain has an average slope of about 8 feet to the mile; and it is assumed that this plain extends to the eastward under the waters of the lake. If it retains the same slope a cliff 24 feet in hightwould represent a terrace at least 3 miles broad. It is probable that the wave cut terrace varies between 2 and 4 miles along this portion of the shore.

From Zapatera northward to Granada the wave action is more efficient than on any other portion of the lake by reason of the greater sweep which the prevailing winds and waves possess. Since the shore is here composed of only partially consolidated volcanic ash, the modification of its outline, due to wave action, has been very considerable. It is probable that this action has severed Zapatera from the mainland, and that the many islands surrounding it were originally portions of that volcanic cone. They probably represent the more resistant lavas from which the softer materials have been washed away.

The modification of the northeast shore of the lake by wave action has been extremely slight. This portion of the lake shore is without a beach, and only rarely is there any considerable surf; hence only a few points which project well out into the lake show any effect of wave action.

The material eroded by the waves from the western shore has been carried north by the action of the waves and deposited in the upper end of the lake. A bar has been built across the point of the lake, enclosing a broad, shallow lagoon behind it, and the outlet of lake Managua has been pushed northward by the sand drift well toward the northern margin of the valley.

Alluviation.-The third way in which the outline of the lake has been modified is by the building out of its shores by material brought down by tributary streams. The effect of this is seen almost exclusively along the south and east shores. Elsewhere the constant surf and consequent littoral currents have been sufficient to distribute the sediment as rapidly as brought down by tributary streams, so that not only have no additions been made to the lake shore, but the new material added has not been sufficient to compensate for the wave erosion. When the waters first occupied the depression behind the barrier to the northwest, the outline of the lake must have been quite irregular, since it filled a river basin some portions of which had rather strong relief. Much of its basin occu- 
pies a region which had been comparatively well baseleveled, but its waters also extended up the valleys, where extensive unreduced areas remained upon the divides. Many shallow estuaries were thus formed, and these have subsequently been entirely filled with sediment by the streams entering their heads. The most extensive filling was at the southeast end of the lake, where the largest tributaries enter it. It is evident that the broad swampy plains bordering the Rio Frio and the upper San Juan, down to and beyond the Toro rapids, were originally portions of the lake which ihave subsequently been silted up. The ordinary method by which lakes are obliterated is by the filling from their upper ends and by the cutting down at their outlets. In this case, however, a part of this process is exactly reversed. The lake is being filled most rapidly from its lower end. This filling is manifestly accomplished not by the water which comes from the lake, since this is practically clear, but by the tributaries which enter this lower portion.

The present river channel does not necessarily coincide with the position of the river which formerly occupied this basin. Its present position is dependent on the relative amounts of sediment brought down by the tributaries on either side. If the Castillo and Toro rapids were cut back and the channel of the river permitted to sink through the alluvium forming the greater part of its banks and bed on the oldland surface which the alluvium conceals, it would have the characteristics of a superposed stream. At numerous points where its present channel does not follow the old channel it would discover hard rocks in its downward cutting. In its present condition this may be described as a residual river channel-that is, a broad arm of the lake has been gradually constricted by the addition of sediments on its margin-and all that remains is the narrow river channel kept open by the current of the water flowing from the lake.

The Toro rapids, which retain the lake at its present level, are not formed by a solid ledge of rocks crossing the valley, but by boulders, sand, and clay. It is some distance below the Toro rapids that the rock is first found crossing the valley.

It appears that when this arm of the lake extended down to the Continental divide it received a rather large and swift tributary, the Rio Sabalos, near its head. The sediment carried by the Sabalos, consisting of clay, sand and boulders, was deposited on reaching the quiet water of the lake. A delta was thus formed which extended across this arm of the lake, forming a shoal. As the river channel sank in the gap across the divide the latter became lower than the surface of the Sabalos delta, and the crest of the dam, which retained the surface of lake Nicaragua, moved west from its original position on the divide to the present posi- 
tion of the Toro rapids. It is evident that the dam formed of this unconsolidated material is only very temporary, and that the backward cutting of the river channel, unless artificially checked, will soon lower this barrier and eventually affect the level of the lake.

It is difficult to determine exactly the position of the old divide. It undoubtedly crossed the valley of the present San Juan below the mouth of the Poco Sol. That stream has evidently inherited the lower portion of its course from a tributary to the stream flowing northwest. The Santa Cruz also probably belonged to the western drainage. The general course of the Bartola, on the other hand, indicates that it belonged to the eastern system; hence the divide was probably between the Bartola and the Santa Cruz. It may have been at the present Castillo rapids, although it is probable that the rapids would show some recession due to erosion since the lake was formed. This, however, might be comparatively little by reason of the character of the rocks and the fact that the river at this point carries comparatively little coarse sediment, and hence is relatively inefficient in corrading its channel.

\section{Summary AND Conclusion}

1. The region discussed embraces the belt of country extending from the Caribbean sea to the Pacific in northern Costa Rica and southern Nicaragua adjacent to the route of the proposed Nicaragua canal.

2. Its most important physiographic feature is the broad depression which extends diagonally across the isthmus between the recent volcanic ranges on the southwest and the Chontales hills on the northeast. The topography of this depression is chiefly that of an oldland, generally reduced to the condition of a peneplain by streams flowing in opposite directions from a former divide near the axis of the isthmus.

3. The rainfall on the Caribbean side of the isthmus is very abundant and distributed uniformly throughout the year. On the Pacific side it is less abundant and confined to half the year. This climatic difference produces striking differences in vegetation, rock decay, rate of erosion, and resulting topographic forms.

4. The rocks of the region are largely volcanic products, with two sedimentary formations of Tertiary (Oligocene) age, and no rocks occur which are certainly alder than the Tertiary. The igneous rocks are in part contemporaneous with the Tertiary sedimentary formations and in part recent.

5. On the east side high temperature with abundant moisture and consequent rank and rapidly decaying vegetation afford exceptionally favorable conditions for rock decay, which has extended to great depths 
and yields red clay as the final product. On the west side alternate wet and dry seasons afford less favorable conditions for rock decay, and the final product is blue clay.

6. In early Tertiary (Oligocene) time there was probably free communication across this portion of the isthmus between the Atlantic and the Pacific. A great mass of sediments was deposited in a shallow sea and many volcanoes were in active eruption.

7. In middle Tertiary time the region was elevated and subjected to long continued subaerial degradation, and the narrower portion of the isthmus was reduced to a peneplain, with monadnocks at the divide near the axis. There is no evidence that open communication has existed between the two oceans across this portion of the isthmus since the middle Tertiary uplift.

8. In post-Tertiary time the region was again elevated and the previously developed peneplain deeply trenched.

9. A recent slight subsidence has drowned the lower courses of the river valleys, and the estuaries thus formed have subsequently been filled with alluvial deposits.

10. Recent volcanic eruptions have formed a barrier across the outlet of a bay which formerly indented the Pacific coast. The waters rose behind this barrier until they reached the level of a low gap in the Continental divide, when they discharged to the eastward, and the divide was shifted to the newly formed land near the Pacific coast. Lakes Managua and Nicaragua thus occupy the bed of the former bay and the basins of rivers which were tributary to it. 